\title{
عنوان الاراسة
}
استراتيجية مقترحة في تنمية مهارات الكتابة الإبداعية لاى طالبات
الصف الثاني الثانوي

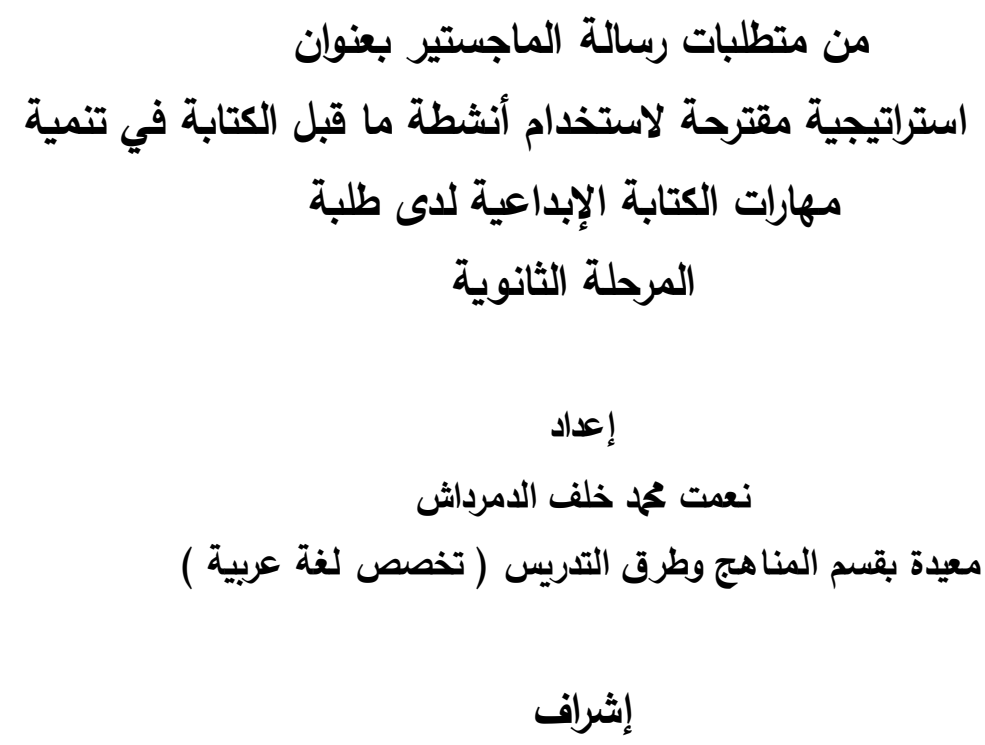

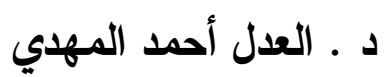

أ. أد / محمد حسن المرسي

مدرس المناهج وطرق التدريس

كلية التربية ببورسعيد

أستاذ المناهج وطرق تدريس اللغة العربية

جامعة قناة السويس لتونيد

كلية التربية بدمياط

جامعة المنصورة

$p^{r} \cdot \Lambda$ 
للتواصل اللغوي جانبان : جانب استقبال ويتمثل في الاستماع والقراءة ، وجانب إرسال ويتمثل

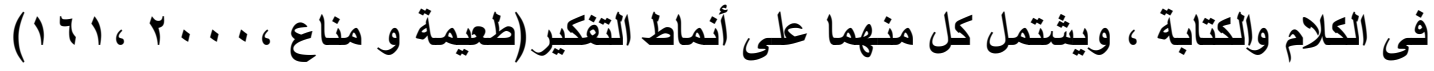

ويثير (مجاور IVV، I991) إلى أهمية الكتابة ضمن جانبي الإرسال ، فيرى أنها أعظم مـا

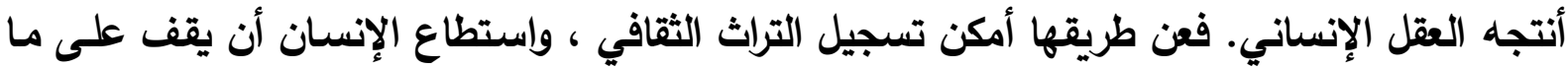
أحدثه غيره من تطورات أثرت فى حياته وفى بناء المجتمعات الآنساتي

وليس أدل على فضل الكتابة وأهميتها من إثارة القرآن الكريم لها ولأداتها ـ وفى هذا المنحى لا

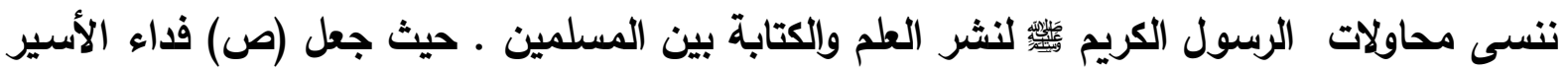
فى غزوة بلدر أن يُعلم عشرة من المسلمين القراءة وإلكتابة.

وينقسم التعبير الكتابي إلى تعبير وظيفي وتعبير إبداعي ، والتعبير الإبداعي - الكتابة الإبداعية -

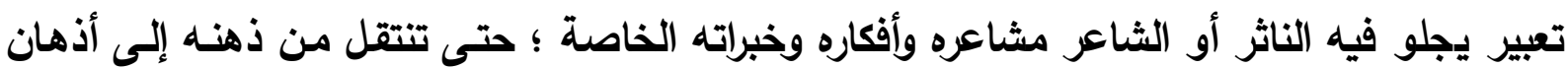

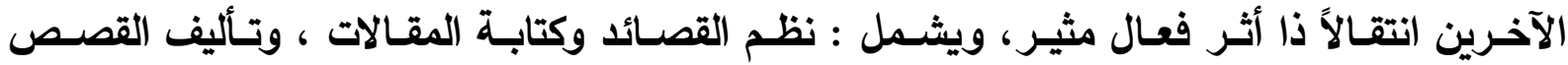

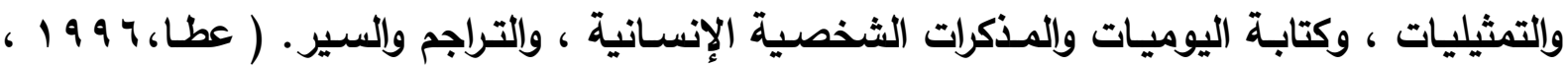
( $1 \vee q-1 \vee \wedge$

وللكتابة الإبداعية مهارات عديدة منها : الدقة في وضع علامات الترقيم ، والتمييز بين الجيد

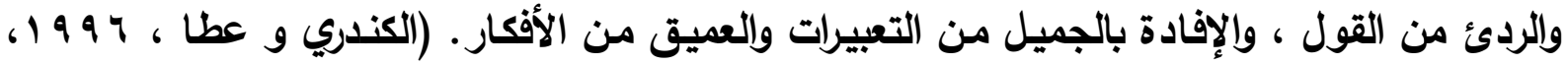

وقد اهتمت العديد من الدراسـات بتنمية مهارات الكتابة الإبداعية مثل دراسـة(Fidalgo,1996)

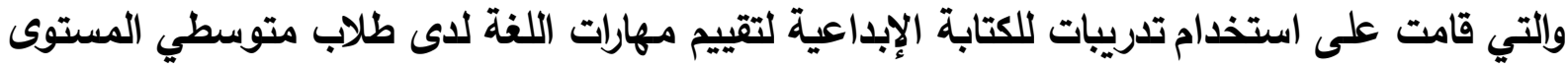
، وقد تم استخدام هذا الأسلوب لدى طلاب الفرقة الثانية بكلية تدريس الإسبانية كبديل عن اختبارات

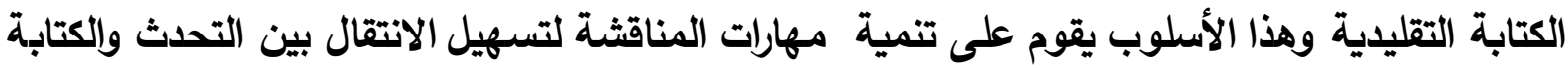

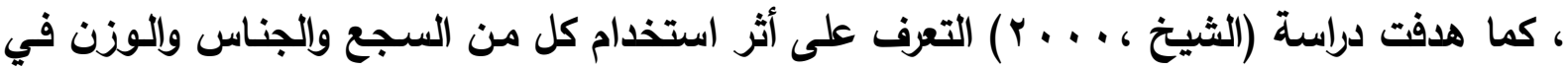

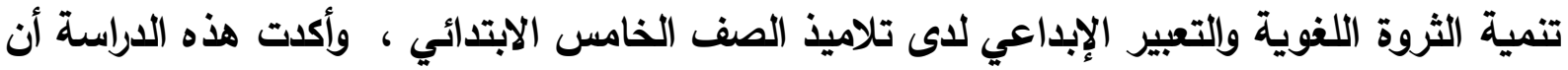

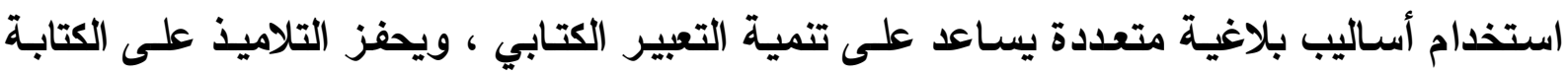




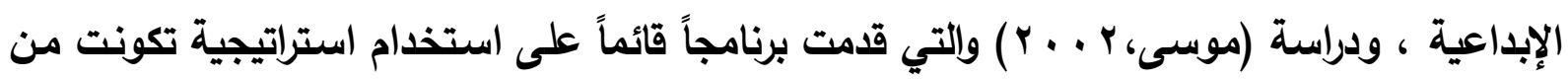

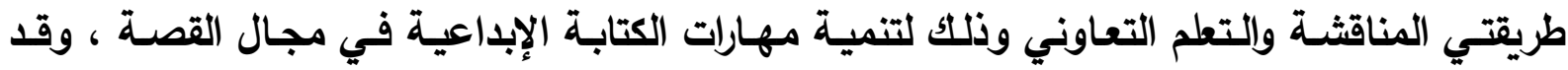
توصلت كل هذه الدراسات إلى فعالية البرامج والاستراتيجيات المستخدمة .

وعلى الرغم من أهمية الكتابة الإبداعية إلا أن الأدبيات والمراجع العربية أكلت وجود قصور

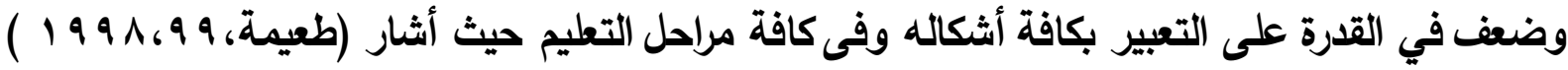

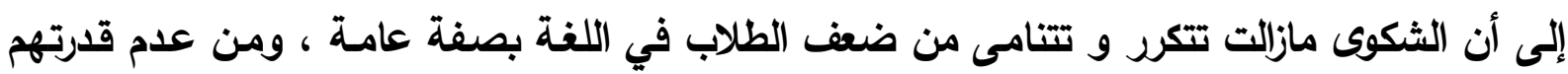

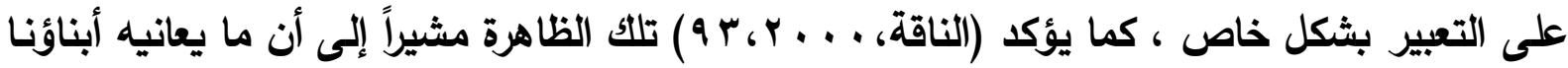

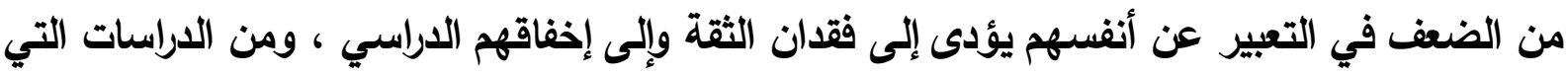

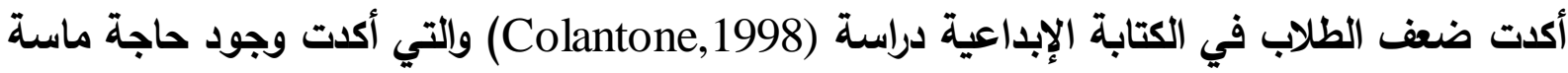

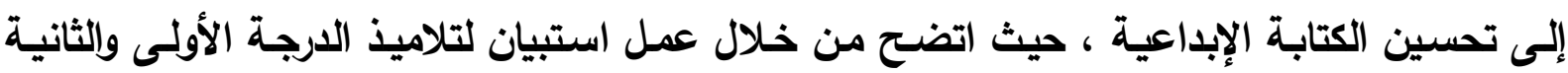

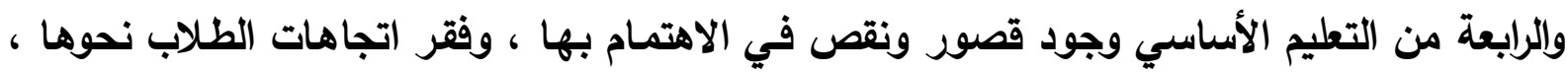

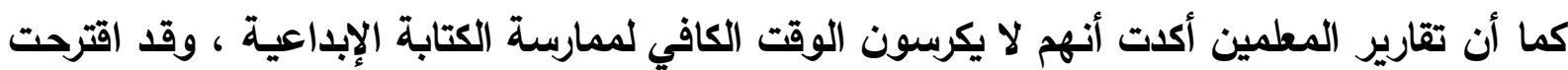

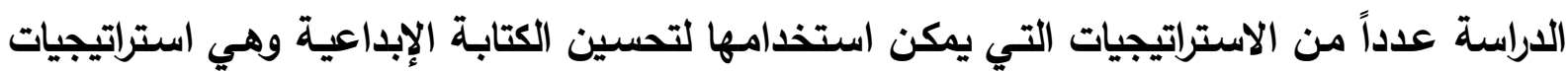

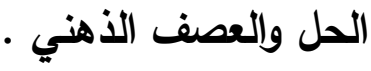

وقد أشارت (الملا و المطاوعة ، 9 V 19 ، به م ) إلى أن طرق التدريس من أهم معوقات تعليم

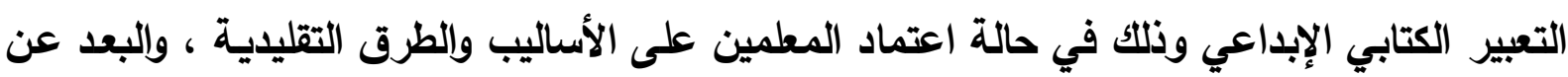

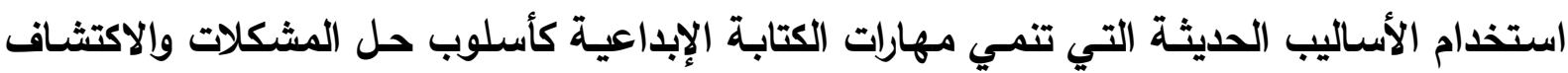

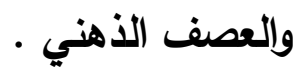

ومن هذا المنطلق شعرت الباحثة بأهمية تجريب استراتيجية مقترحة في هذه الدراسة والتي تألفت

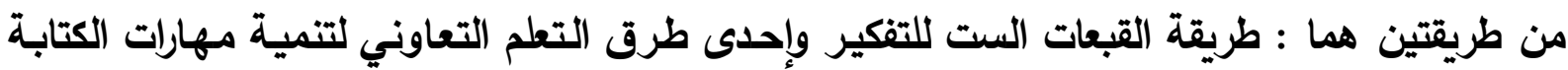

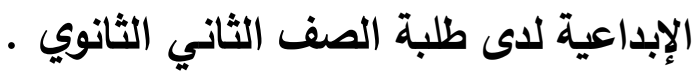

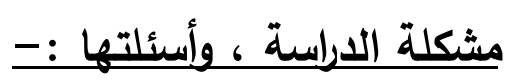
مما سلف يمكن تحديد مشكلة الدراسة الحالية في تدني مستوى طلبة الصف الثاني الثانوي في

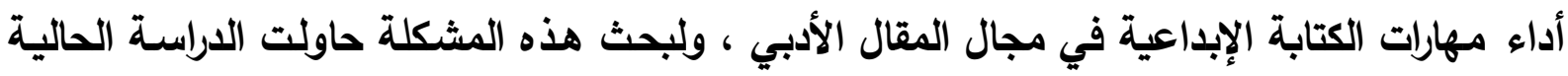
الإجابة عن السؤال الرئيس التالي : 
• ما فاعلية برنامج قائم على استراتيجية مقترحة في تنمية مهارات الكتابة الإبداعية لدى طلبة الصف الثاني الثانوي ؟ بانج

ويتفرع من هذا السؤال الرئيس الأسئلة الفرعية التالية : -

1 - ما مهارات الكتابة الإبداعية في مجال المقال اللازمة لطلبة الصف الثائه الثاني الثاني الثانوي ؟

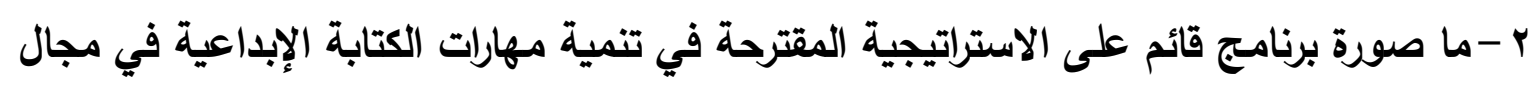

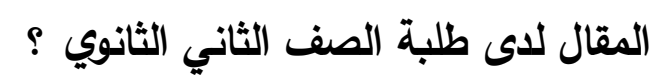
r - ما فاعلية البرنامج القائم على الاستراتيجية المقترحة في مجال المقال لدى لولى طلبة الصف الثاني

الثانوي ؟ مأه

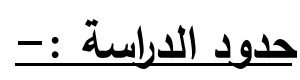

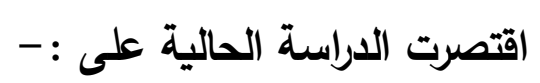

1 - عينة عشوائية من طالبات الصف الثاني الثانوي بإحدى المدارس الحكومية بمحافظة بورسعيد

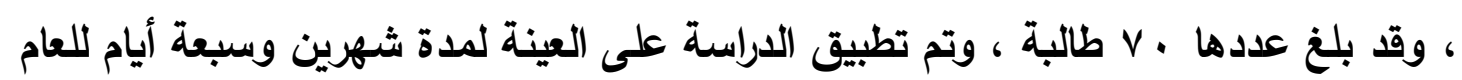

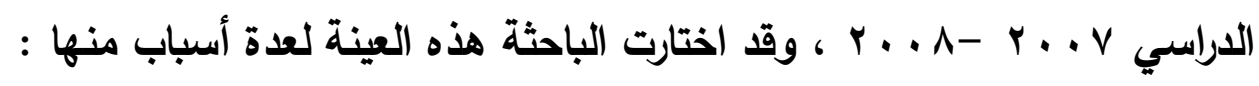

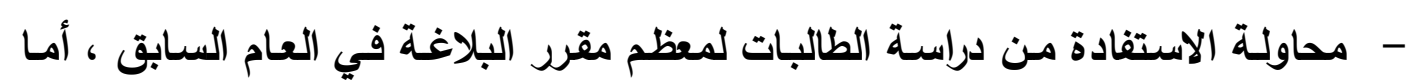

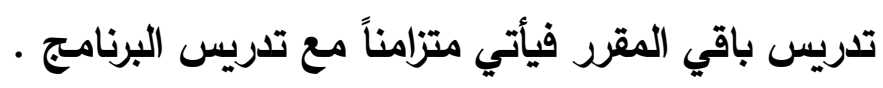

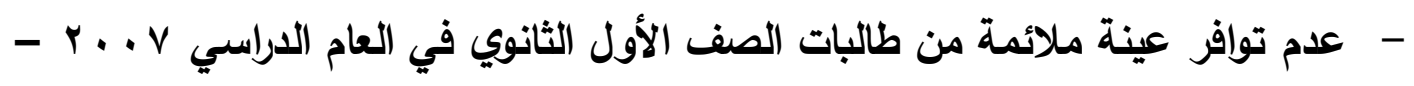
. r. . 1

r - مجال واحد من مجالات الكتابة الإبداعية وهو المقال ، وذلك لعدة أسباب منها : - أنه المجال الأكثر شيوعاً في الاستخدام في المرحلة الثانوية .

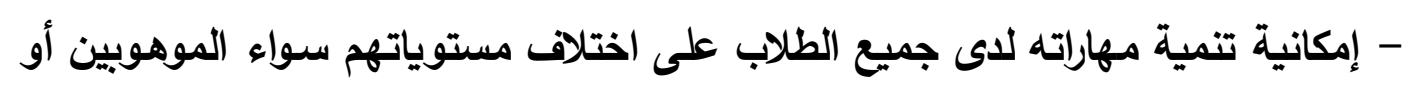
العاديين مانهاته

r - بعض مهارات الكتابة الإبداعية في مجال المقال والمناسبة لعينة الدراسة .

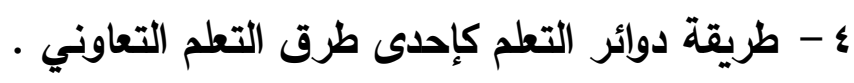
أهمية الاراسة :- تُيسر للطلاب تعلم مهارات الكتابة الإبداعية ، وتنمي لديهم مهارات المقال الأدبي من خلال الاستراتيجية المقترحة واستخدام أنشطة متنوعة. 


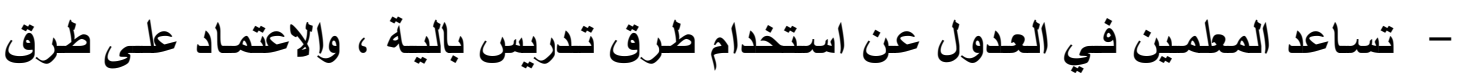
واستراتيجيات حديثة في التدريس مثل الاستراتيجية المقترحة في الدراسة الحالية .

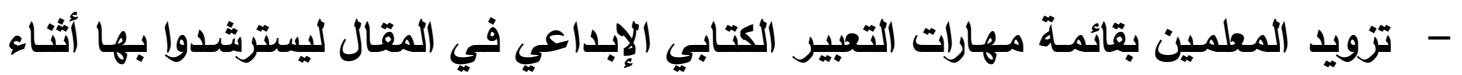

$$
\text { تدريسهم التعبير الإبداعي • ترويد }
$$

- - حيث توجيه أنظار موجهي اللغة العربية في المرحلة الثانوية إلى ما يمكن للمعلم القيام به من إجراءات وخطوات لاستخدام الاستراتيجية المقترحة في تنمية مهارات الكتابة الإبداعية في المقال لاى طلابهم. - تساهم في إرشاد مخططي المناهج في اللغة العربية إلى تحديد أهداف التعبير الكتابي

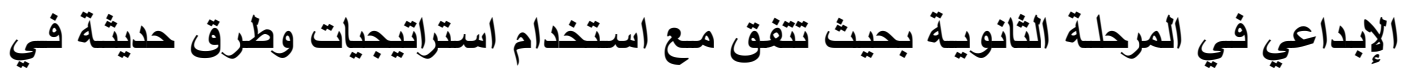

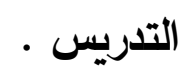

$$
\text { منهج الدراسة :- }
$$

1 - استخدمت الدراسة الحالية المنهج الوصفي في عرض الإطار النظري لمتغيرات الدراسة .

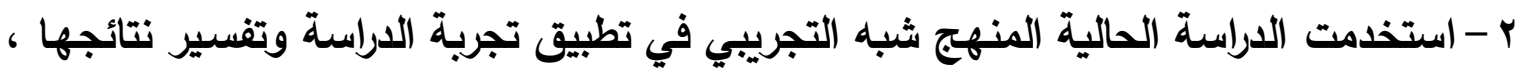
وقد تم استخدام أحد تصميماته وهو تصميم المجموعتين ( ضابطة و تجريبية ) ذي القياس فئهي القبلي والبعدي.

$$
\text { أدوات الدراسة :- }
$$

ا - قائمة بمهارات الكتابة الإبداعية في مجال المقال اللازمة لعينة الدراسة .

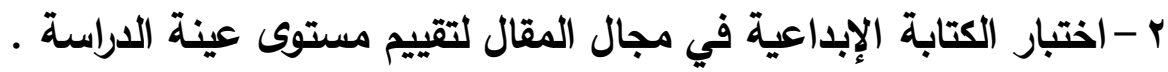

\section{مصطلحات الدراسة :}

استراتيجية: وهي مجموعة من الأفكار والمبادئ التي تتناول مجالاً من مجالات المعرفة الإنسانية ،

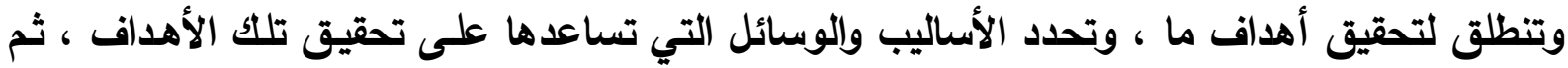
تضع أساليب التقويم المناسبة للتعرف على مدى نجاحها في تحقيق الأهداف ـ (اللقاني و الجمل ، الأسل (19.1999

و تعرف إجرائياً في الدراسـة الحاليـة بأنها : إطـار عـام مخطط لـهـ ، ويتضـمن مجموعـة مـن

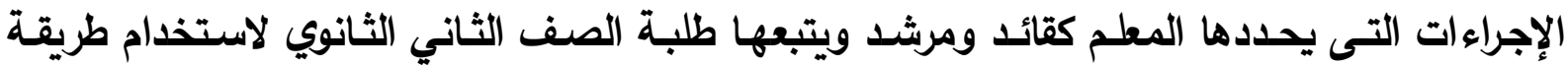
القبعات الست في شكل مجموعات صغيرة ؛ وذلك لتحقيق الهـف المرجو منها وهو تنمية مهارات الكتابة الإبداعية في المقال لايهم . 


\section{الكتابة الإبداعية :}

وتعرف بأنها تعبير عن الذات وأحاسيس النفس في صـورة قصيدة أو مقالـة أدبية أو قصـة . .

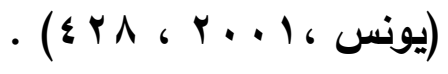

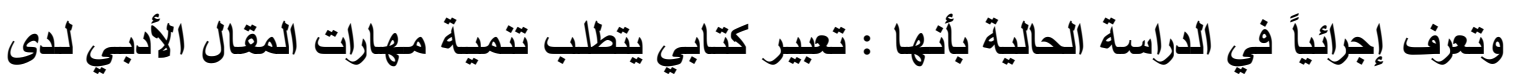
طلبة الصف الثاني الثانوي في ثلاثة أبعاد هي ( الأصالة والطلاقة وإلمرونة ) ـ ل المهيارة:

والمهارة في مجال التربية : هي القدرة على أداء عمل ما في سرعة ودقة .

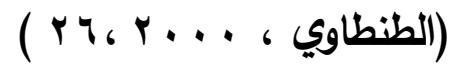

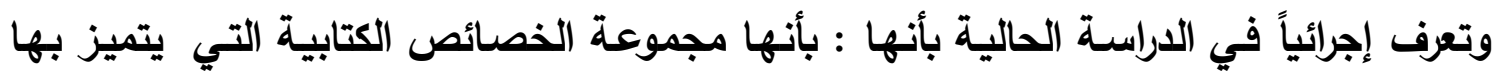
المقال الأدبي والمستهاف تنميتها لاى طلبة الصف الثاني الثانوي من خلال مراحل عملية الكتابة وهي ( ما قبل الكتابة - التأليف والإنتاج - المراجعة والتعديل ) .

\section{الادراسات والبحوث السابقة}

أولاً : دراسات وبحوث اهتمت بتنمية مهارات الكتابة الإبداعية في مراحل تعليمية مختلفة أ. الدراسات العربية : دات وبحوب:

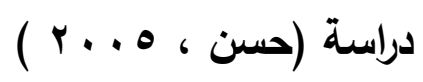

وقد هدفت التحقق من أثر استخدام المدخل التفاوضسي وأسلوب الحافظة في تنمية مهارات

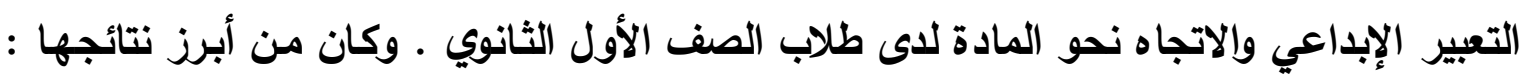

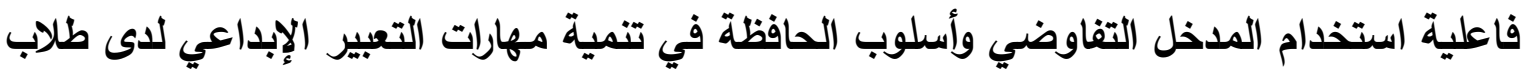
المجموعتين التجريبيتين • واكتساب طلاب المجموعتين التجريبيتين اتجاه إيجابي نحو مادة التعبير

$$
\text { الإبداعي المجموعين }
$$

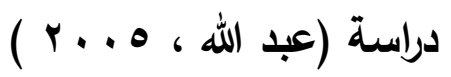

والتي هدفت التعرف على مدى فاعلية برنامج مقترح في التمكن من بعض مهارات التعبير الكتابي

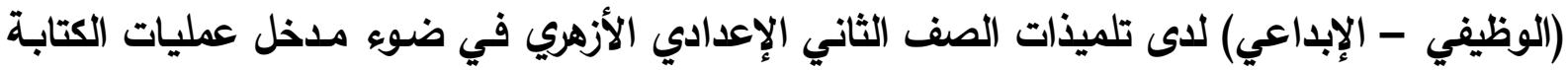
- التفاعلي

وكان من أبرز نتائجها : فعالية البرنامج في تنمية مهارات التعبير الكتابي الوظيفي في مجالي

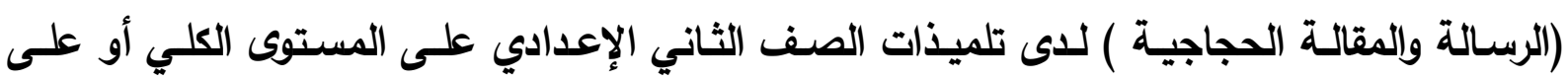


المستوى كل مهارة على حده ـ كنلك فعالية البرنامج الحالي في تنمية مهارات التعبير الكتابي الإبداعي

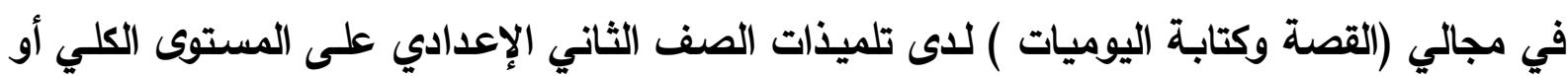

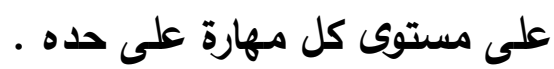

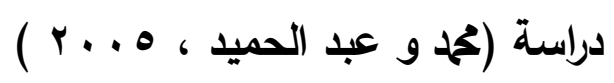

هدفت التحقق من فاعلية برنـامج مقترح باستخدام العصف الذهني في في تنمية الكتابة الإبداعية

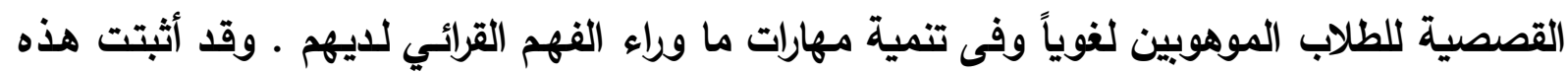

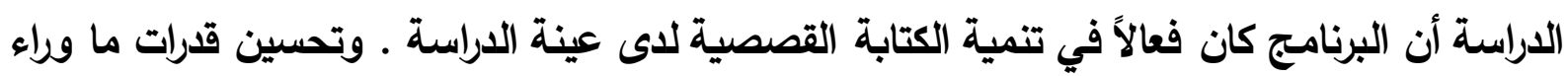

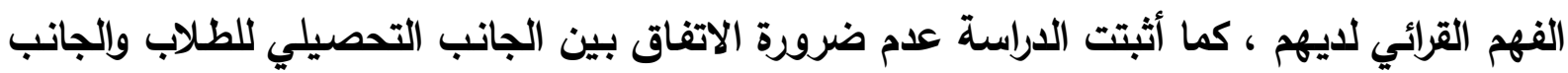
الإبداعي لليهم ، وهذا يعنى أن الإبداع القصصي لا يعتمد بثكل أساسي على القئ القدرة التحصيلية

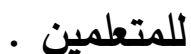

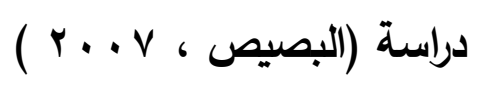

وقد هدفت التحقق من فاعلية برنامج مقترح في ضوء استوات التراتيجيات الذكاءات المتعددة في تنمية

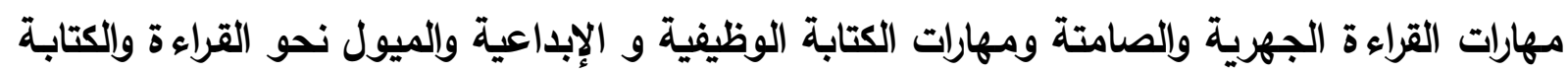

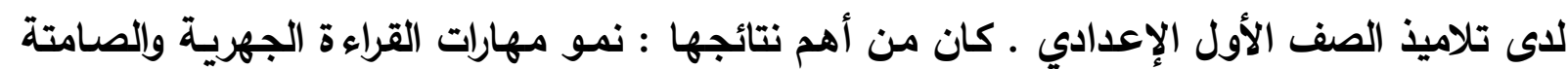

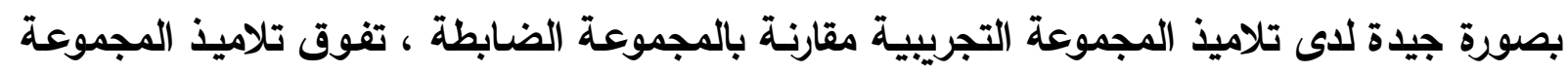

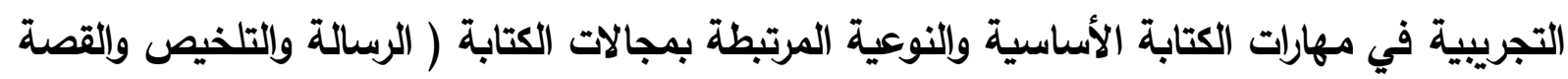

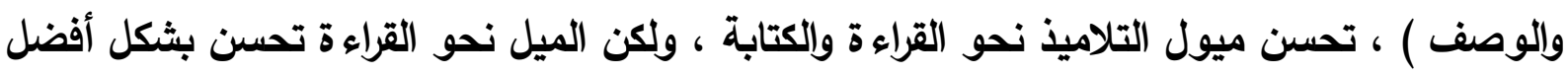

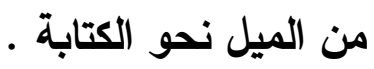

\section{ب. الاراسات الأجنية :}

دراسة ( Colantone, and Others , 1998 ) هدفت هذه الدراسـة التحقق من فاعلية برنامسج مقترح لتنمية مهارات الكتابة الإبداعية ودعم قدرات

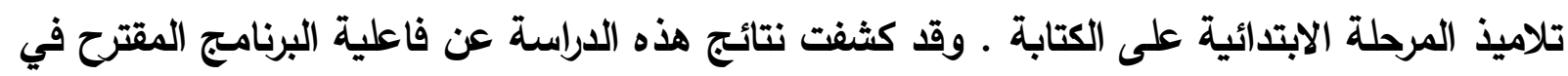
تنمية مهارات الكتابة الإبداعية للى عينة الدراسة ـ كما أظهر الطلاب تحسناً ملحوظاً في كتاباتهم حيث أصبحوا أكثر طلاقة في التعبير عما كلفوا به . دراسة ( Abu rass , 2001 ) 
وهدفت التحقق من فاعلية منهج تكاملي للقراءة والكتابة قائم على تزويد الطلاب العرب بقراءة الأدب

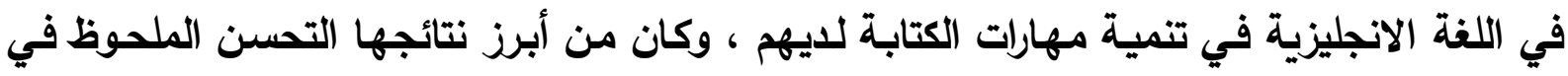

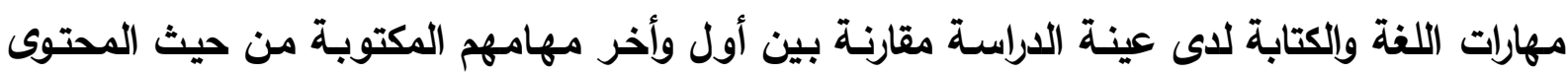

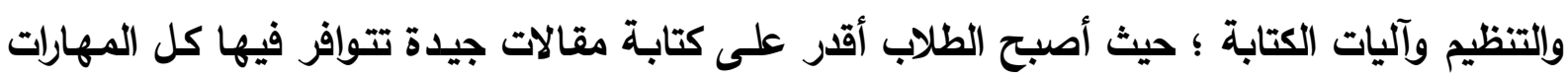

$$
\text { المطلوبة . }
$$

هدفت هذه الدراسـة التحقق من دور اللعب في تطور الكتابـة الإبداعية لدى طلاب

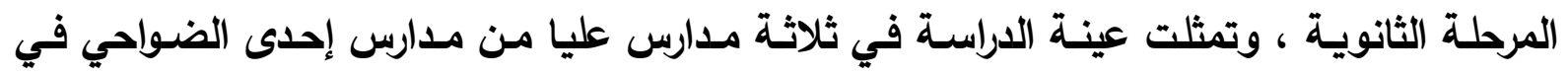

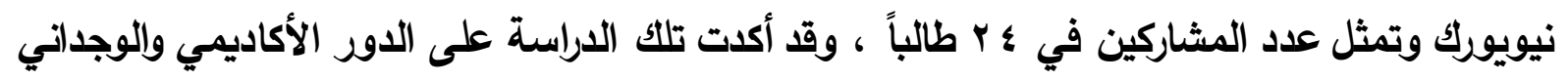

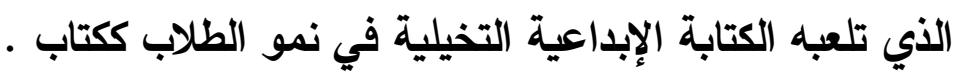

المحور الثاني دراسات وبحوث اهتمت باستخدام طريقة القبعات الست للتفكير في تنمية الإبداع في

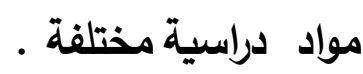

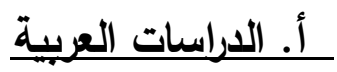

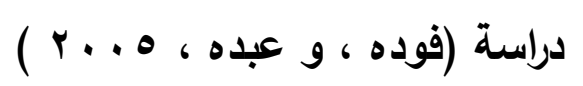

هدفت معرفة أثر استخدام فنية دي بونو للقبعات الست في تلدريس العلوم على تنمية نزعات التفكير

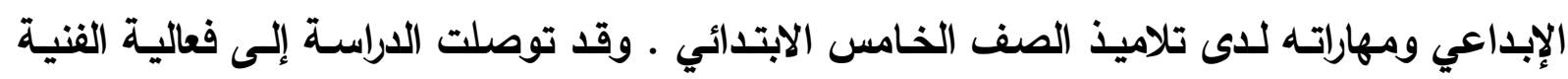

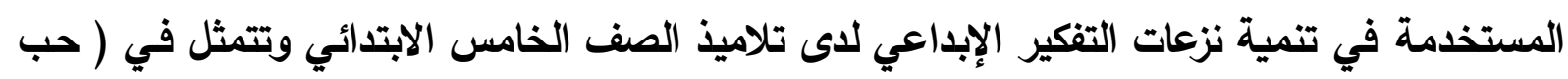

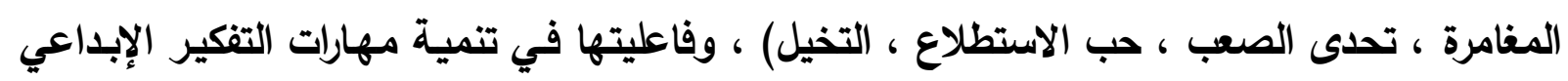

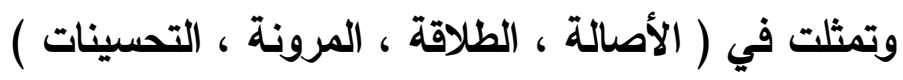

\section{بـ الدراسات الأجنيية : دراسة ( Carl , 1996 )}

هدفت هـذه الدراسـة تقصس العلاقـة بـين مستوى الجـدال للطـلاب ( أي اتخـاذ مواقف حـول

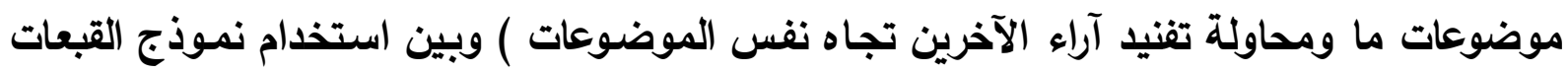

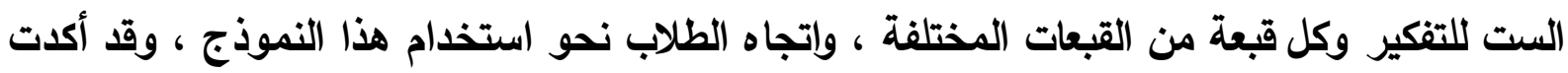

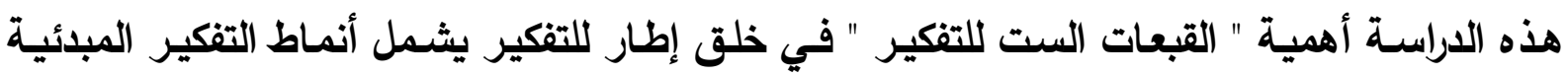

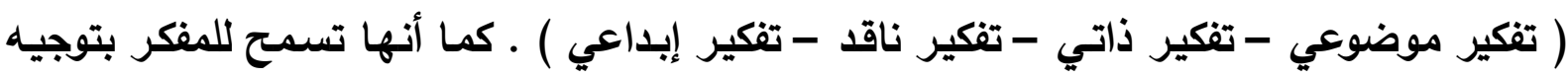

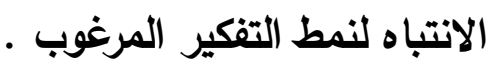


دراسة ( Jervis , 1998 )

هدفت تلك الداسـة تقييم منهج التكنولوجيا لطلاب المـارس الثانوية من خلال برنـامج يقوم على الثى

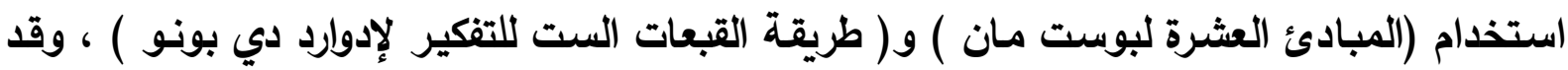

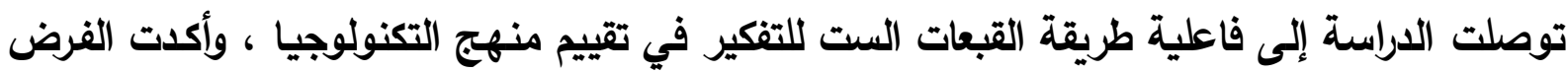

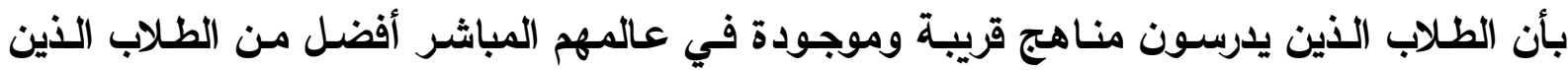

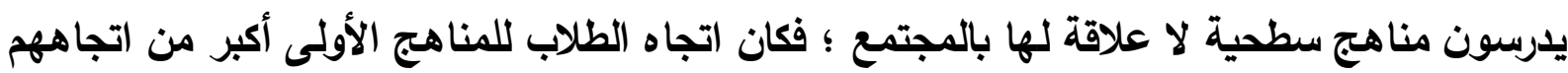

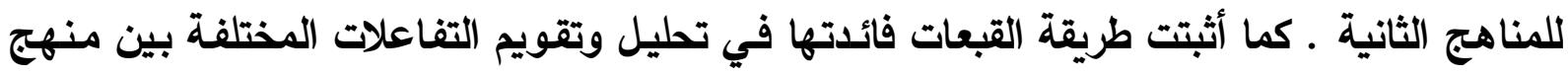
التكنولوجيا والمجتمع سواء كانت تفاعلات اقتصادية أو علمية أو ثقافية . دراسة (Ericson, 2003 هدفت هذه الاراسة تعرف أسباب استخدام طريقة القبعات الست للتفكير في المدارس الابتدائية في

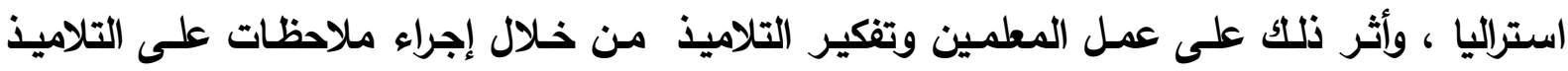

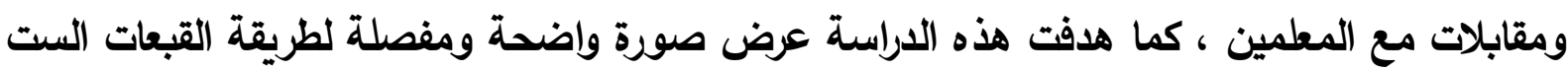
للتفكير والتهاف الأساسي لكل قبعة منها ، وقد أوضحت نتائج التهات المقابلات أن كل المعلمين تكونت لايهح

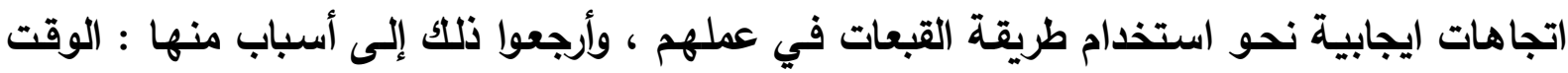

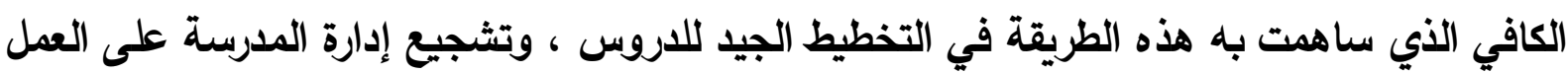

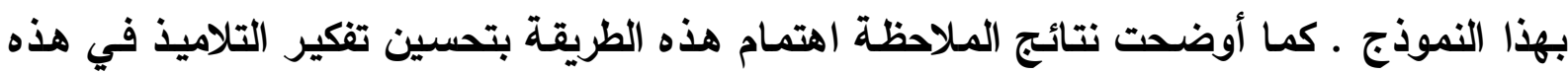
المرحلة ، وأصبح لايهم القدرة على التفكير فيما وراء التفكير .

المحور الثالث : بحوث ودراسات اهتمت باستخدام طريقة التعلم التعاوني في تنمية مهارات الكتابة .

$$
\text { داسة (الدراسات العربية }
$$

وهدفت التحقق من فاعلية استخدام بعض مداخل تدريس التعبير الكتابي الحديثة وهى (التعم التعاوني

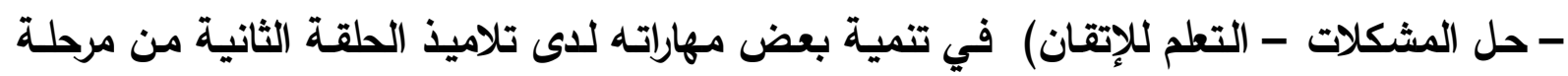

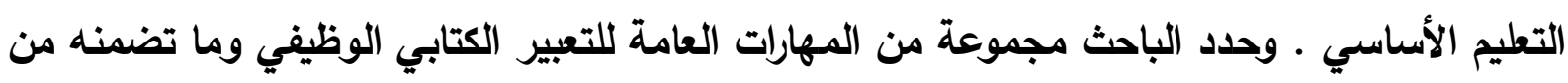

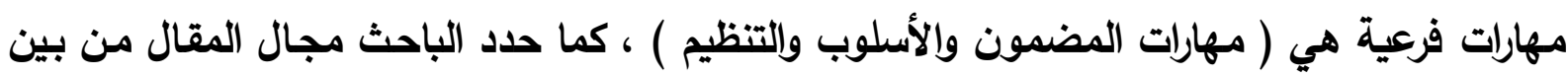

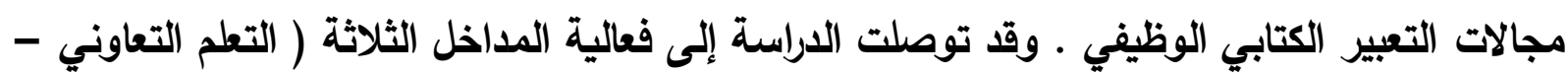

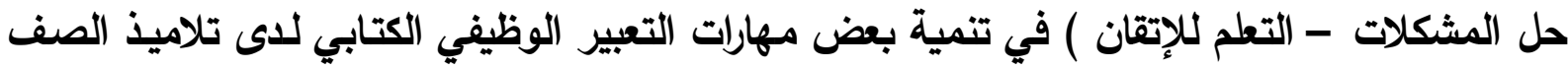


السادس من مرحلة التعليم الأساسي وذلك بالنسبة لكل مهارة من مهارات المضمون والأسلوب وإلتنيم وبالنسبة لمجموع المحاور من مرعه ل

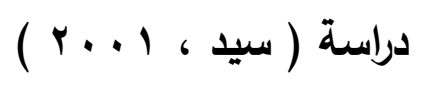

وهدفت تحديد أثر مدخل اختيار الطلاب لموضوعات التعبير ومواقفه ، ثم ممارسة التعبير فيها شفهياً

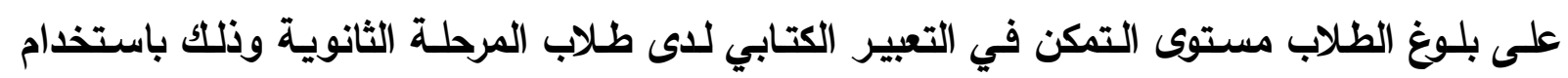

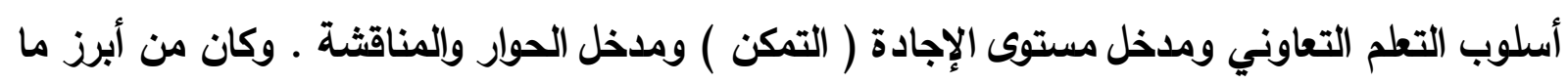

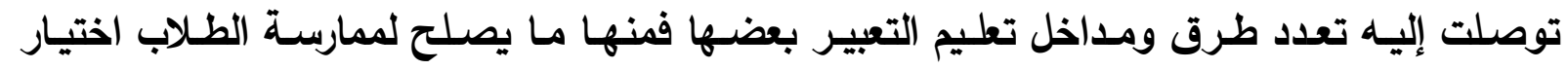

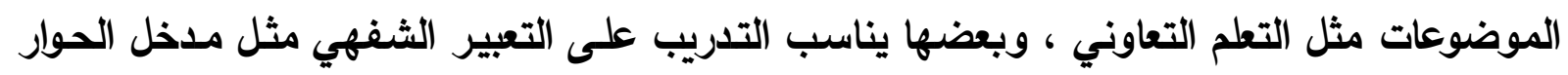
والمناقشة ، وبعضها يناسب ممارسة التعبير الكتابي مثل مدخل مستوى التمكن .

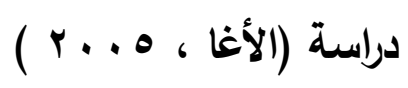

هدفت بحث فعالية استخدام كل من ملفات الإنجاز والتعلم التعاوني في تنمية مهارات التعبير الكتابي

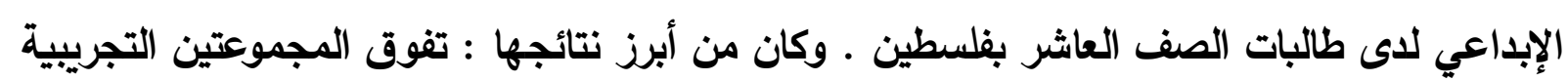
الأولى والثانية ( ملفات الإنجاز - التعلم التعاوني ) على المجموعة الضابطة - حيث أظهرت الثلى النتائج وجود فروق بين المجموعتين التجريبيتين وبين المجموعة الضابطة ، تفوق المجموعة الأولى ( ملفات الاتحان

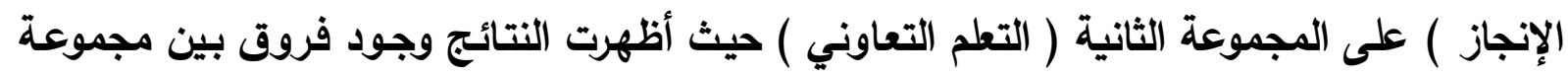
التطم بملفات الإنجاز ومجموعة التعم التعاوني لصالح مجموعة ملفات الإنجاز

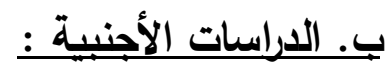
دراسة) (Risk , 2002

هدفت التحقق من أثر الكتابة التعاونية باستخدام الإنترنت في تحسين كتابة المقال لاى طلاب

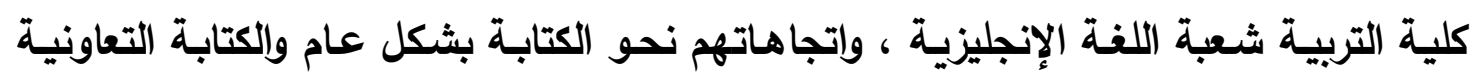

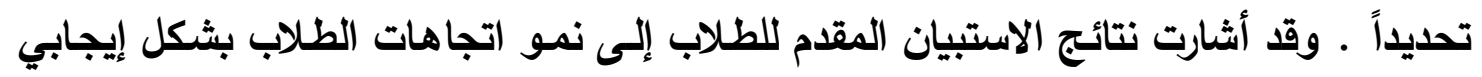

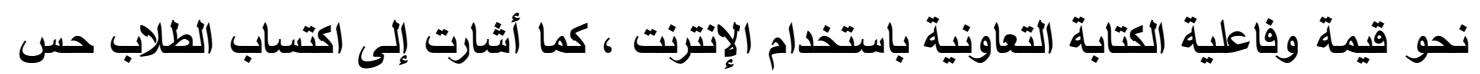
أعلى ووعى بمدى تفاعل المتلقي .

دراسة (Nowlin and Amare , 2003) 
هافت تحديد التأثيرات الإيجابية للكتابة الجدلية التعاونية ، ومقارنتها بالكتابة الفردية التنافسية ، وأثر

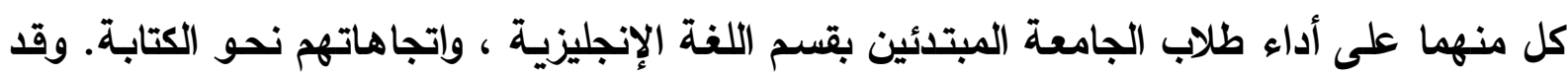

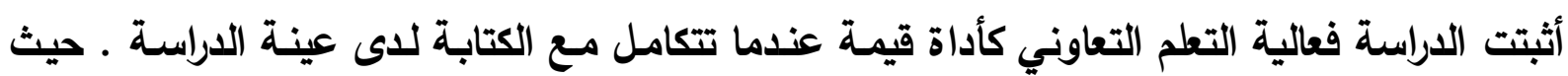

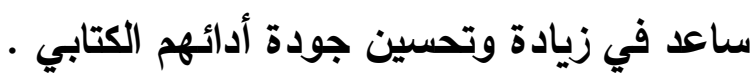

دراسة ( El-Shirpini , 2006 )

هدفت تعرف فعالية استخدام استراتيجيتي التعلم التعاوني والتعلم التنافسي في تحسين الأداء الكتابي

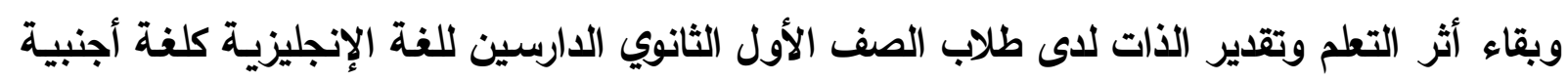

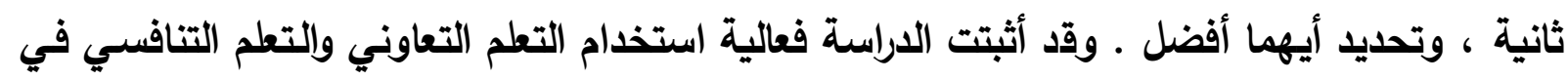

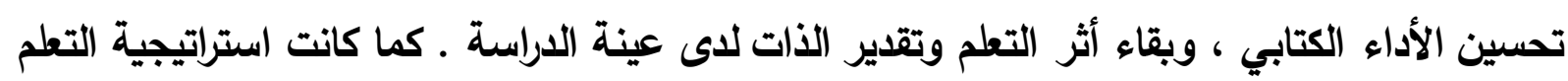

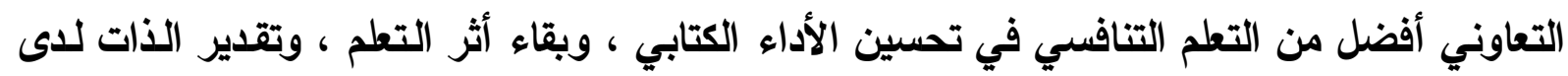

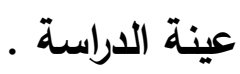

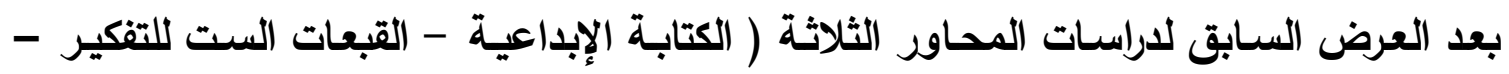
التعلم التعاوني ) يمكن حصر أوجه الاستفادة منها في الدراسة الحالية في النقاط التالية :

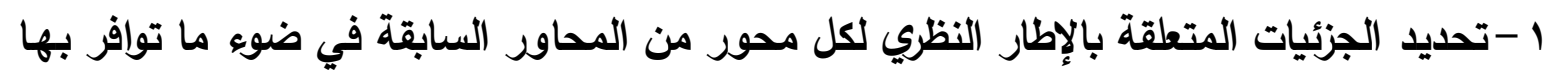
من إطار نظري . بايل ץ - -صياغة فرض الداسة ، وقد تم اختيار مستوى دلالة عند ه ه. .. على الرغم من فعالية التعلم

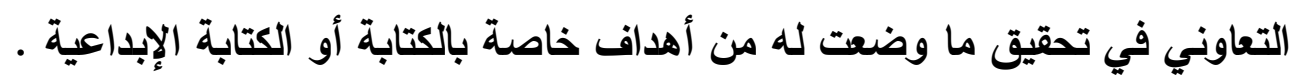

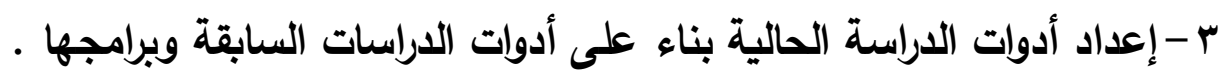

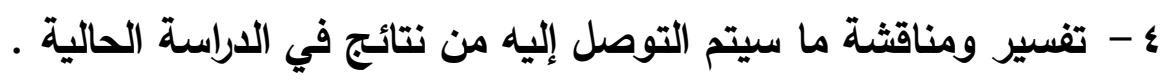

\section{الإطار النظري}

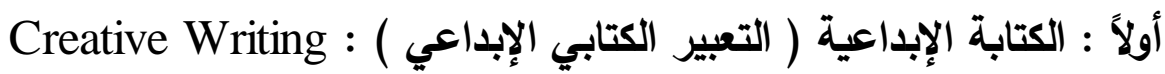

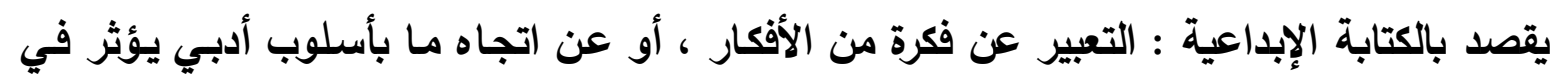

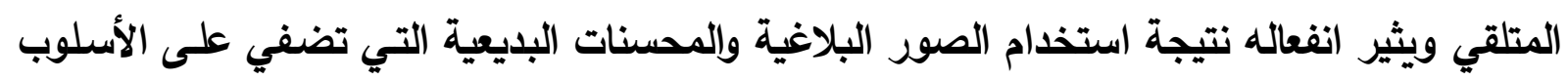

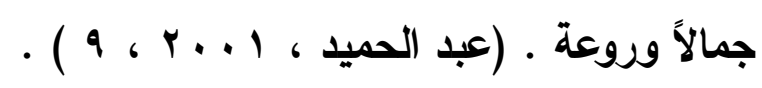


كمـا ميز ( تثــارلز بروجز ورونالــ لنسفور ) بـين ثلاثـة أنـواع رئيسـة مـن الكتابـة هـي :

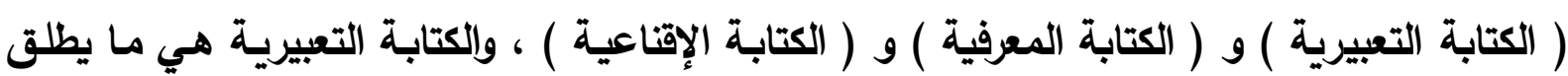
عليها في التربية : ( الكتابة الإبداعية ) والتي يعبر فيها الفرد عن أفكاره الذاتية الأصلية وبيني أفكاره

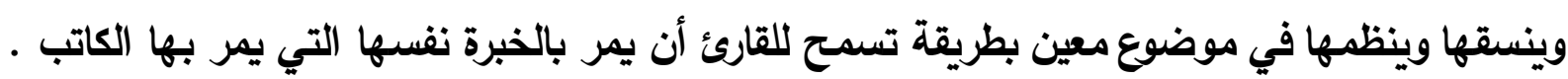

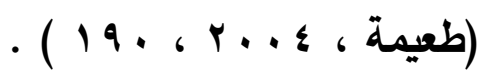

مهاراتها

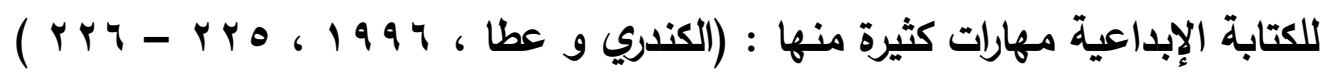

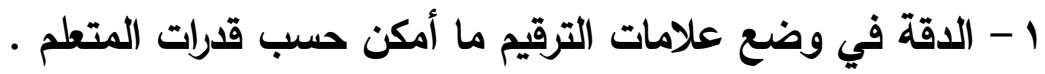

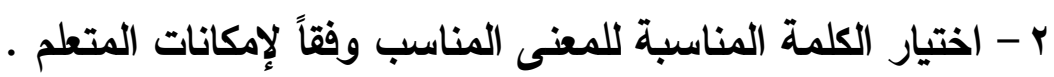

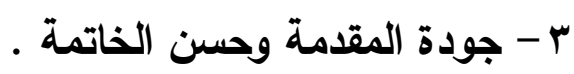

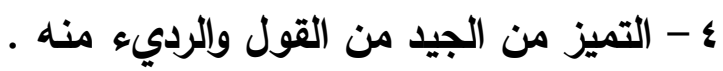

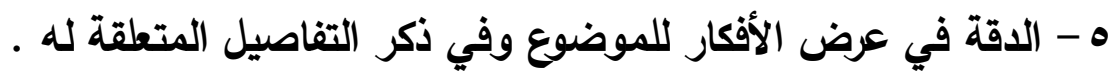
4 - الإفادة بالجميل من التعبيرات العميقة من الأفكار التي يقرؤها التلميذ . V - جودة كتابة الفقرات وحسن ترابطها ـ - ل 1 - ترتيب الجمل داخل فقرة واحدة . أهميتها من فوائد هذا النوع من الكتابة ما يلي : - الكيابة 1 - تعد الكتابة الإبداعية - التي تتضمن كتابة المذكرات والثعر والقصص القصيرة - وسيلة قيمة

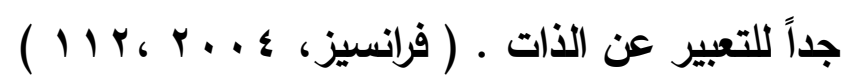

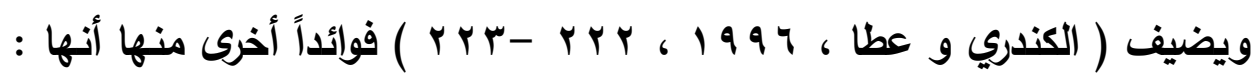
r - تساعد على نمو شخصيات التلاميذ وتكاملها .

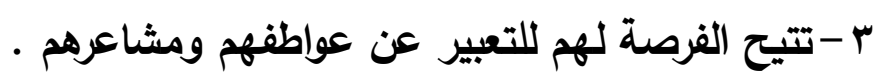

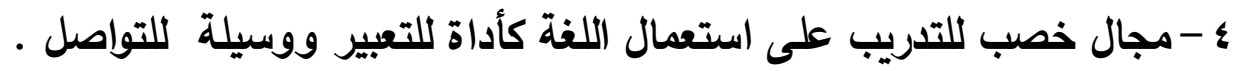

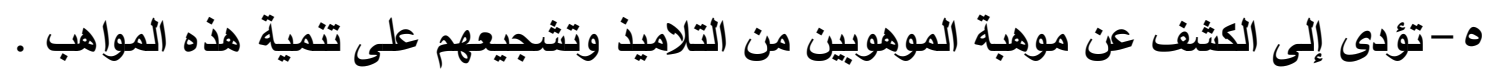

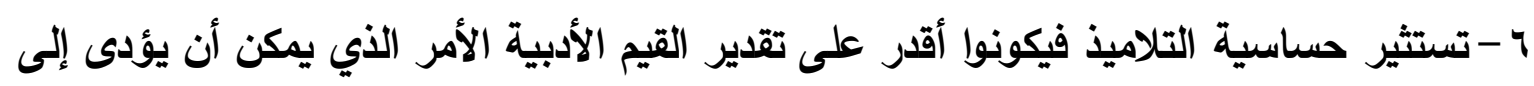
تذوق الجمال والتفاعل معه . V - تساعد التلاميذ على الاستمتاع بالآثار الأدبية الجميلـة ، والإقبال على الكتابة التي تشبع حاجاتهم وميولهم بعيداً عن الإسفاف والتدني . 


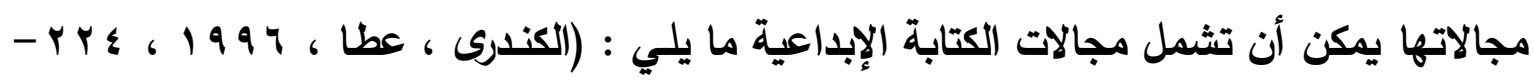
(rTo أ - كتابة المقالات ( سياسية - اجتماعية - أدبية ) . ب - كتابة القصص والمسرحيات

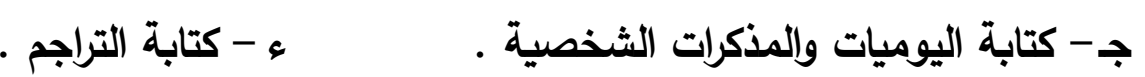
و - التعبير عن المعاني والقيم الإنسانية

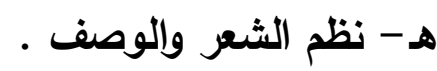
ومعالجة الموضوعات الاجتماعية والنقدية . ز - موضوعات حرة يميل التلاميذ إلى كتابتها

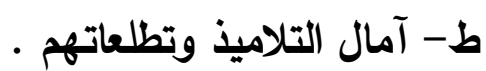
ح- موضوعات تتصل بالفنون المختلفة .

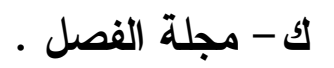

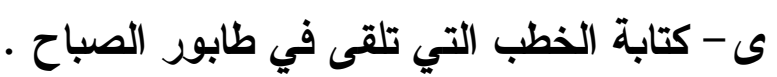
وسوف تقتصر الدراسة الحالية على مجال واحد من مجالات الكتابة الإبداعية وهو المقال .

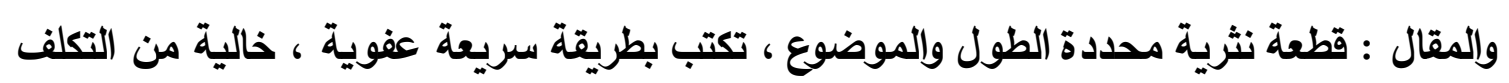

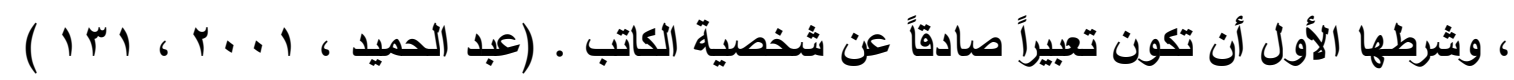

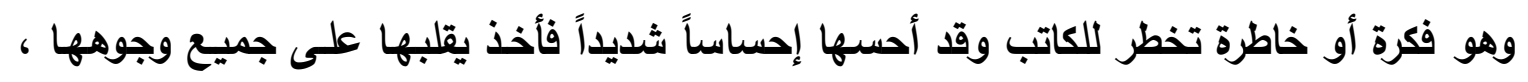

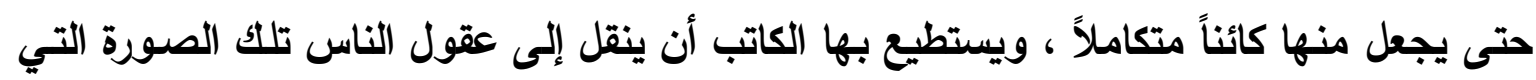

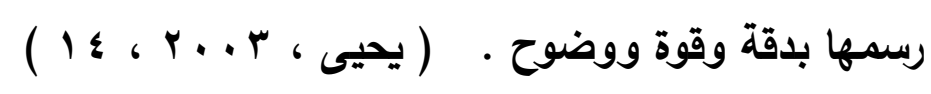

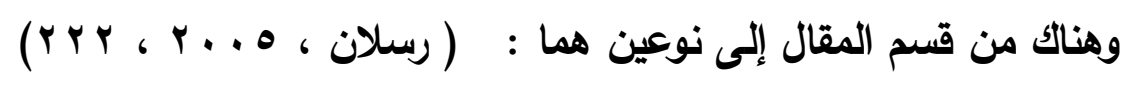

1 - المقال الذاتي : ويعنى إبراز شخصية الكاتب من خـلال أسلوب أدبـي ملـئ بالعاطفـة والانفعال والألفاظ الموحية . r - المقال الموضوعي : ويتم فيه عرض الموضوع بأسلوب واضح وبسيط ودقيق ، ويتسم

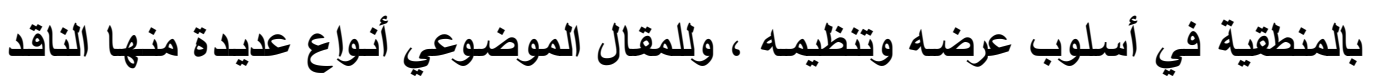

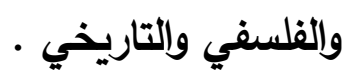

وبناء على ذلك سوف تقتصر الدراسـة الحالية على تدريس المقال الأدبي ( الذاتي ) باستخدام البرنامج القائم على الاستراتيجية المقترحة .

طرق تنميتها من الطرق والأسـاليب التي يمكن أن يعتمد عليها المطـم في تنمية الإبـاع والتعبير الإبـاعي ( الكتابة الإبداعية) لاى طلابه ما يلي: 


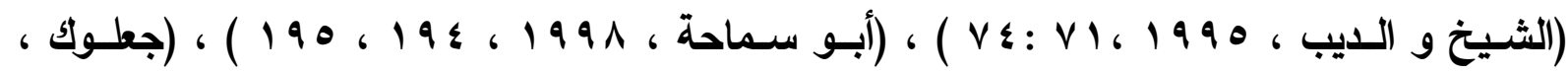

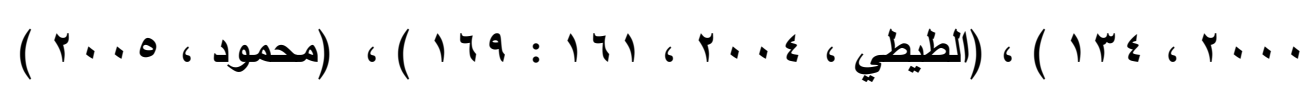

1 العصف الذهني : Brain Storming

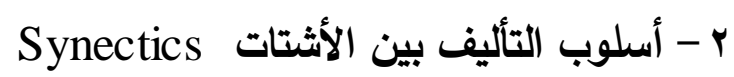

Guided Discovery الاكتشاف الموجه

عialogue Method - طريقة الحوار

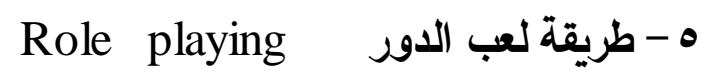

كocio-Drama السوسيودراما

Creative Problem Solving الحل الإبداعي للمشكلات - v

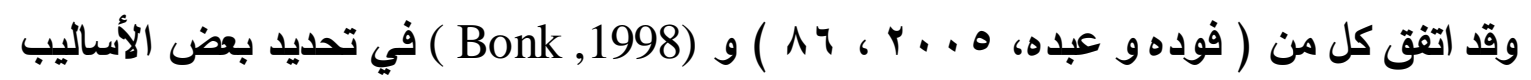

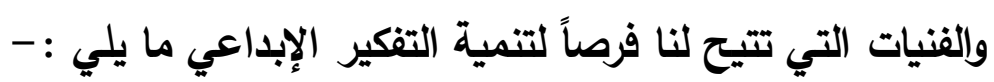

Imitation المحاكاة لئاة

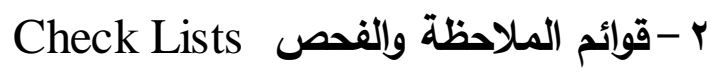

Free Written الكتابة الحرة

ـ - قائمة المواصفات

Problem Reversal عكس المشكلة

צix Thinking Hats القبعات الست للتفكير

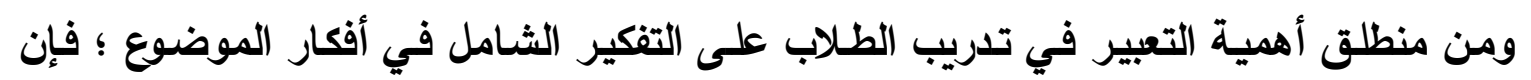
تدريس التعبير لابد أن يعتمد على أساليب وطرق واستراتيجيات تنمى لائ الطلاب مهارات التفكير

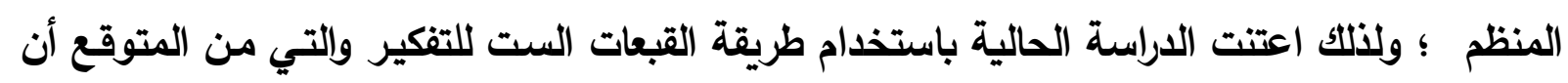
تساهم في تدريب الطلاب على رسم إطار عام للتفكير وإزالة عوائقه التي تشعرهم بالعجز والاضطراب

The Six Thinking Hats طريقة القبعات الست للتفكير - نبذة عن واضع طريقة القبعات الست للتفكير

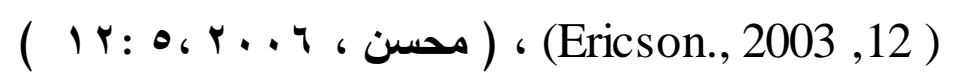

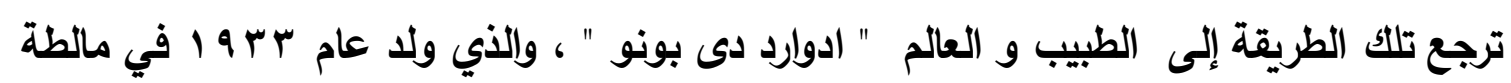

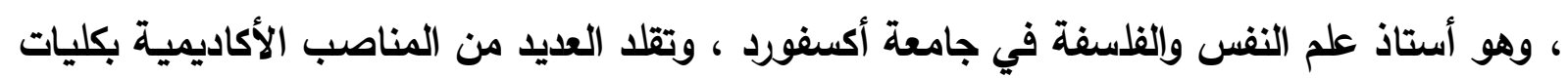

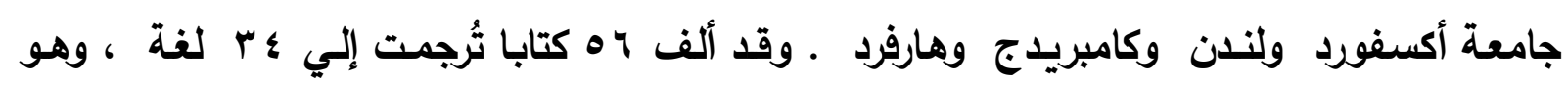




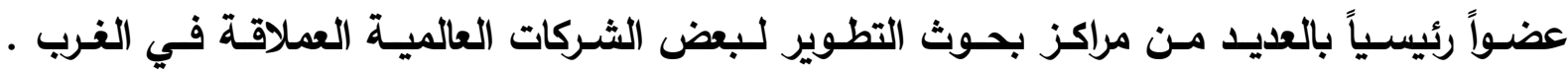
وبالإضافة إلى إسـهامه في وضع طريقة القبعات الست للتفكير ، فقد قدم برنائامجاً منهجياً متكاملاً

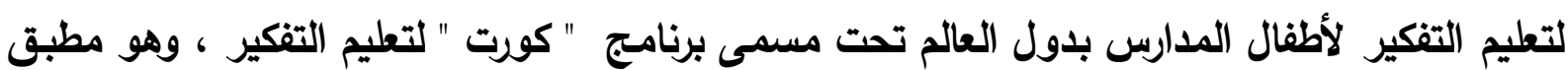

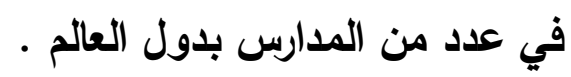

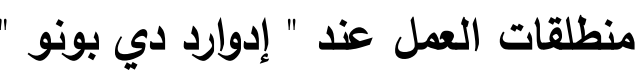

ا-يرى دى بونو أن العقل جهاز ذاتي التظيم ؛ أي أنه يعمل من خلال نماذج خبراتية كونها بنفسه من واقع تفاعله مع المواقف المختلفة في الحياة ، ويُعاود استحضارها

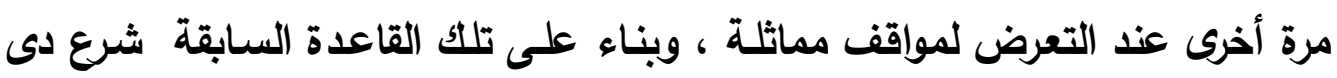
بونو في تصميم أدوات عملية للتفكير ، وقد تميزت بالبساطة والعملية .

ץ-يرى دى بونو أن التفكير مهارة مثل أي مهارة يُمكن للإنسان تعلمها بل وتجويـها ،

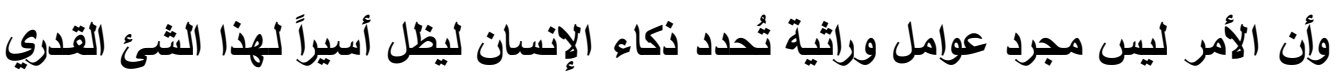
مدى الحياة دون احتمالية تعديله أو تغييره .

r - يرى دى بونو أن الإبداع ليس حكراً على صفوة من الناس ؛ بل أنه يُنادى أن يكون

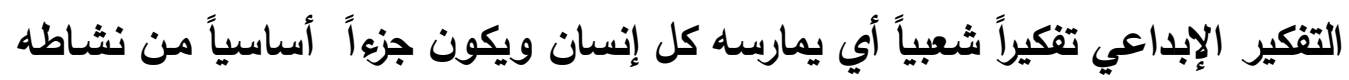
الفكري .

ع - يعتقد دى بونو أنه من الصعب الحصول على أفكار جديدة أو اتخاذ قرارات صحيحة

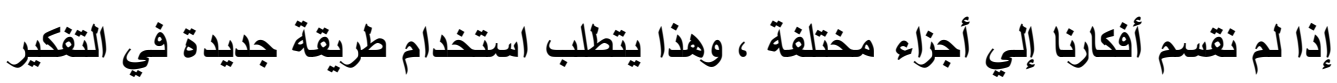

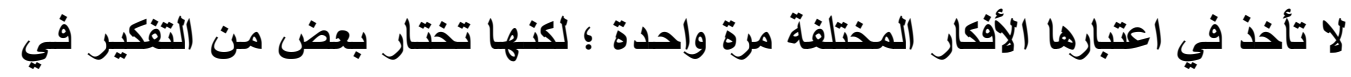

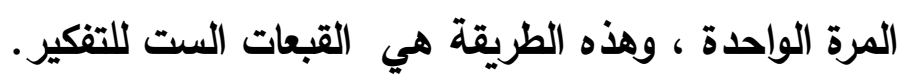
- طريقة القبعات الست للتفكير

انتقل " دي بونو " في تخصصه من الطب إلي الفلسفة ، واستفاد من مطوماته الطبية عن المـخ في تحليل أنماط التفكير عند الناس ، حتى ابتكر طريقة القبعات الست للتفكير في أوائل

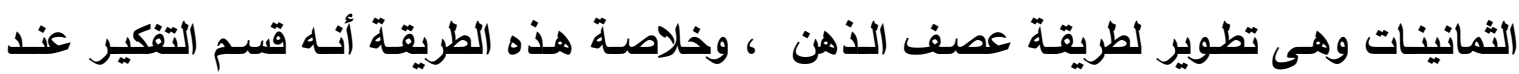

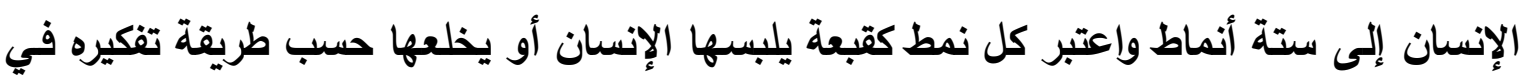
تلك اللحظة ، ولتسهيل الأمر فقد أعطى دي بونو لوناً مميزاً لكل قبعة حتى يمكن تمييزه بسهولة الإنة 
إن هذه الطريقة تسمح بدراسة جوانب الموضوع ، كل جانب في مرة ، بدون ترك نمطواحد من

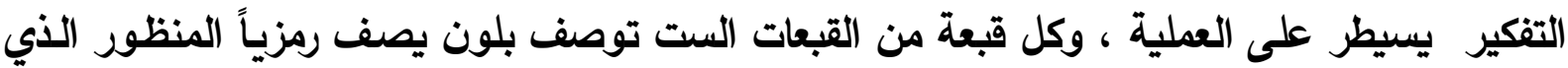

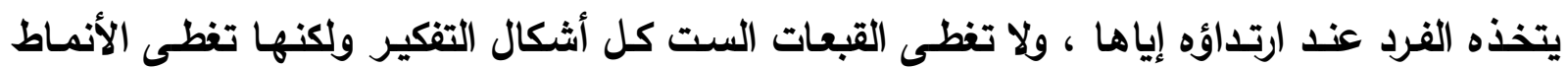

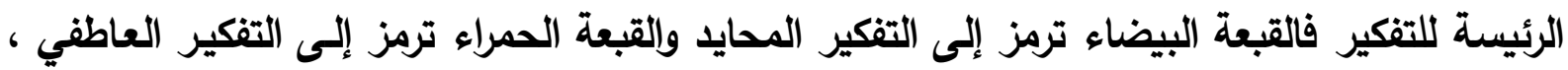

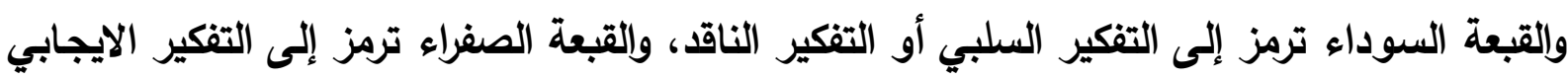

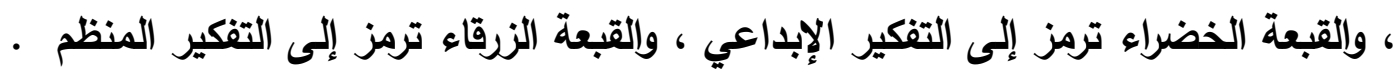

\section{وفيما يلي توضيح لهذه القبعات}

إن كل قبعة من قبعات التفكير الست لها لون مميز ، وتسمى كل قبعة بلونها ، وقد تم استخدام

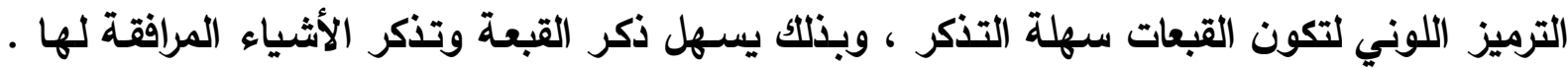

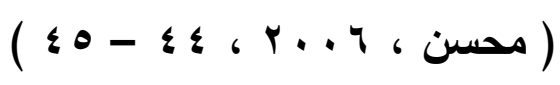

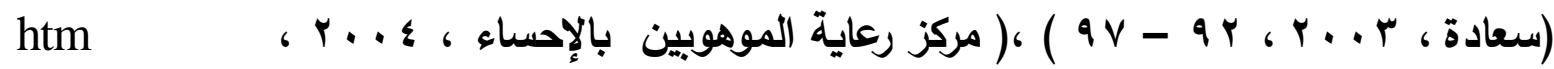

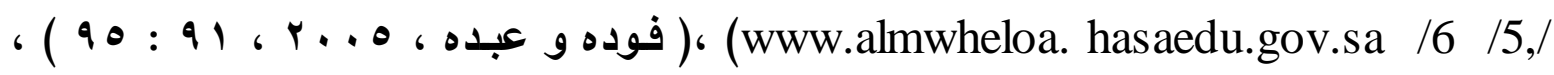

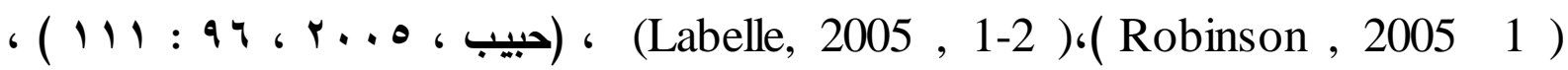

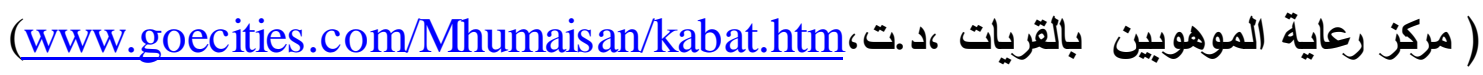

The White Hat القبعة البيضاء وهى قبعة جمع الحقائق والمعلومات والأرقام فالقبعة البيضاء هي قبعة التفكير المحايد الموضوعي

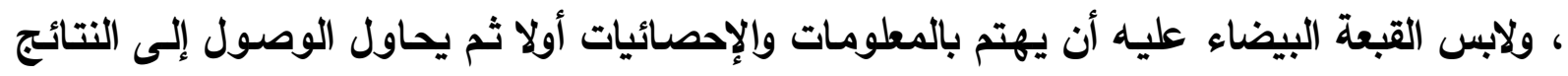

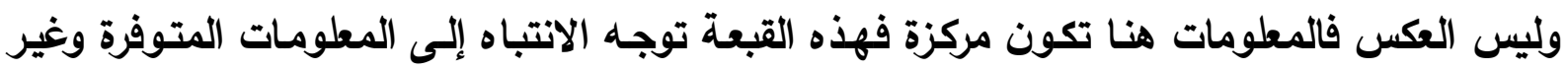
المتوفرة وهى بمثابة (قاعدة بيانات ) * وكل من يرتدى هذه القبعة يسأل هذه الأسئلة:

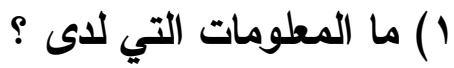

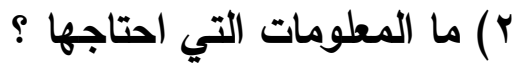

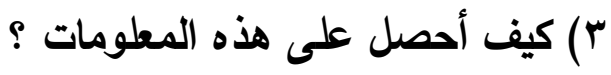

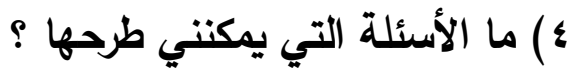

The Red Hat القبعة الحمراء 


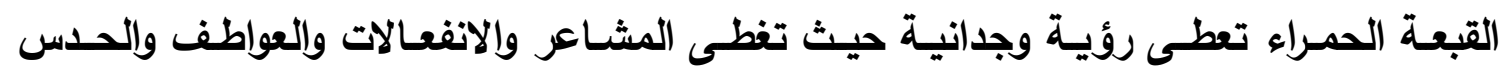

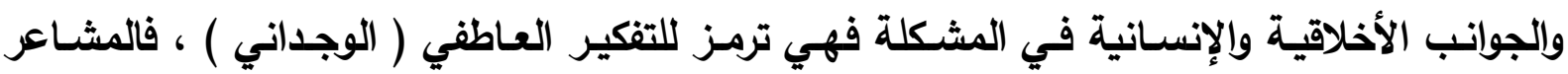
والعواطف قد تكون أصيلة ولكن المنطق يتفوق عليها ، والقبعة الحمراء تعطى للمفكر الذي يرتديها لإليها

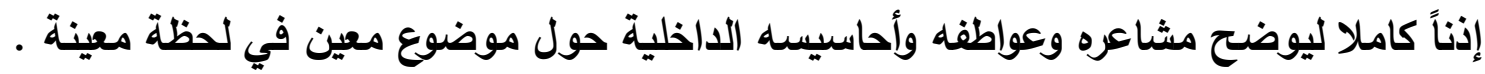

وكل من يرتدى هذه القبعة عليه مراعاة الأتي: التعبير عن مشاعره وأحاسيسه تجاه موضوع ما ، وليس بأيس بالضرورة أن يكون هناك مبرد لهذه المشاعر

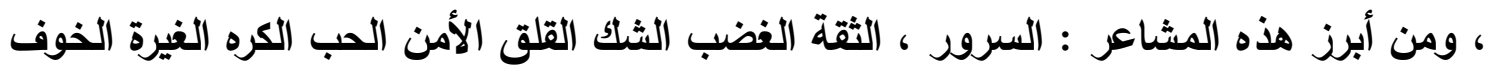
ا - إدراك المشاعر على أنها جزء صالح من التفكير بثرط أن تحدد اتجاهها

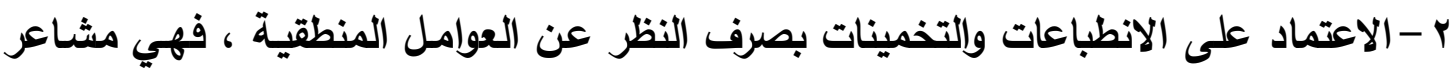

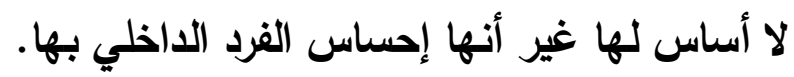

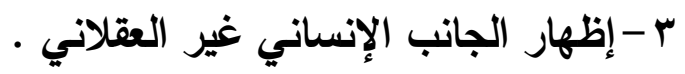
؛ - المبالغة في تحليل الجانب العاطفي ، وإعطائه وزناً أكثر من المعتاد . ه - عدم القيام بأي محاولة لتبرير مشاعره . צ- إظهار المشاعر المختلطة نحو الفكرة ؛ أما إذا احتاج المفكر إلى اتخاذ القرار فهو يحتاج

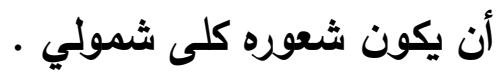

The Black Hat القبعة السوداء وهذه القبعة ذات قيمة مهمة فهي ليست سلبية ولكنها مطلوبة كثيراً عند اتخاذ القرارات ـ كما أنها تعمل على تخفيف ميل الناس إلى النقد لأنها تتيح لصاحبها الحرية في طرح النقد وتقبله من الآخرين

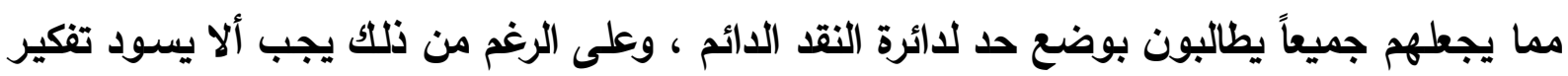
القبعة السوداء على نمط التفكير

وعلى كل من يرتدى هذه القبعة أن يفعل بعض ما يلي : -

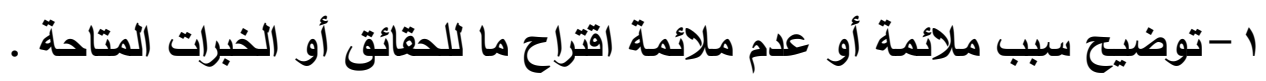

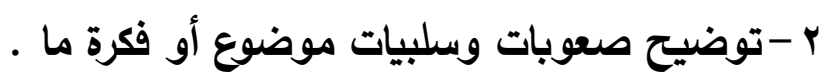

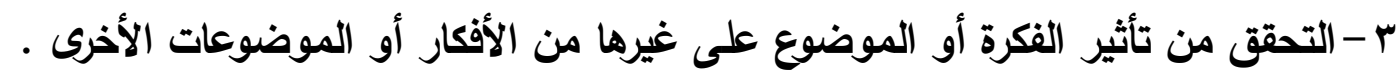
ع - توضيح وإظهار نقاط الضعف في الفكرة .

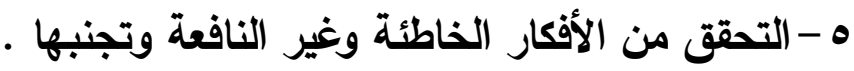


צ- عدم استعمال الانفعالات وإلمثاعر بوضوح ، وإنما نلجأ إلى استعمال المنطق وإظهار الرأي

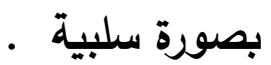

V - نقد الآراء ورفضها ، وربما تلجأ في ذلك إلى المنطق والحجج والأدلة التي تنظر إليها من زاوية

$$
\text { سلبية معتمة . }
$$

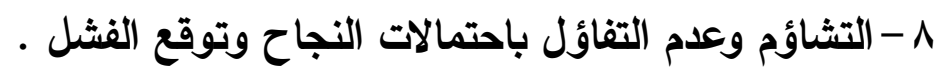

؟ - القبعة الصفراء The Yellow Hat

وتعتبر القبعة الصفراء نقيض القبعة السوداء حيث تهتم قبعة التفكير السوداء بالتفكير السلبي بينما تهتم قبعة التفكير الصفراء بالايجابيات وتسمح بالروئ والأحلام .

وعلى كل من يرتدى القبعة الصفراء أن يهتم بما يلي : -

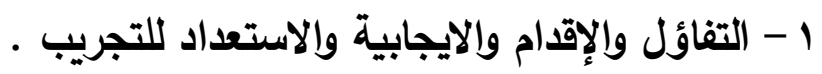

1 - التفكير في النقاط الجيدة في موضول والجابه ولاستعاد أو فكرة معينة

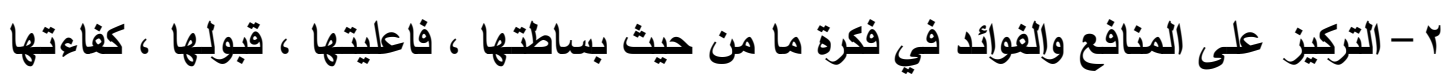

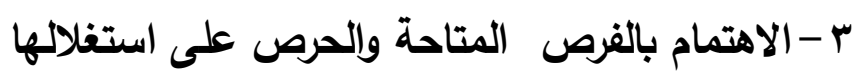
ـ - التركيز على التفكير في انخفاض المخاطرة أو التكلفة

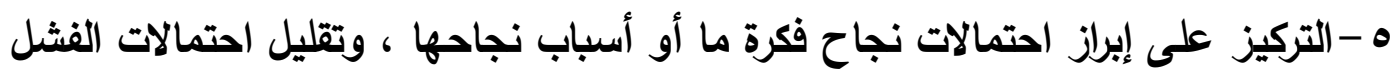

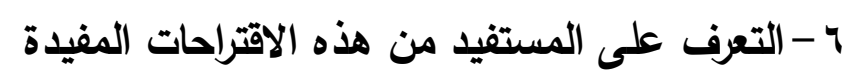
V - Vهوين المشكلات وإلمخاطر ^- وجود أهداف طموحة يعمل نحوها 9 - - 1قوقع النجاح والتشجيع على الإقدام

The Green Hat القبعة الخضراء يتطلب تفكير القبعة الخضراء من الفرد بذل مزيد من الجهد في الحصول على ما يريد بطرق إبداعية

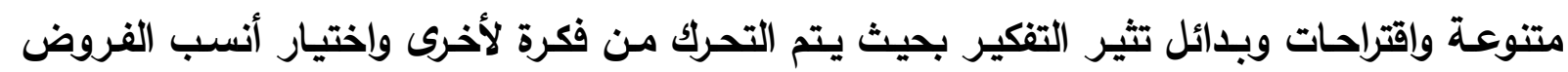
والبدائل ، وبالتالي فاستخدام هذه القبعة يساعد على التقدم للأمام عن طريق إنتاج البدائل .

وعلى كل من يرتدي هذه القبعة مراعاة ما يلي : 1 - الاهتمام بالأفكار والتصميمات الجديدة والإضافية و المحتملة مرأية 
r - التفكير في العواقب المحتمل حدوثها بناء على التفكير في فكرة ما

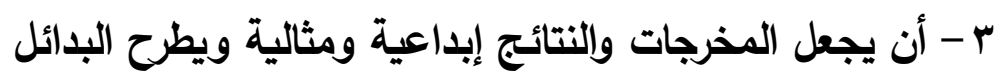

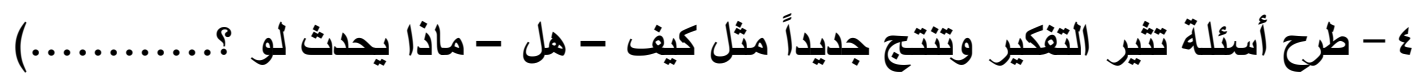
ه - ألا يُمانع في استغراق بعض الوقت والجها للبحث عن الأفكار والبدائل الجديدة

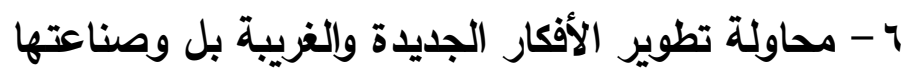

V - الرغبة في التخيل والتفكير العميق

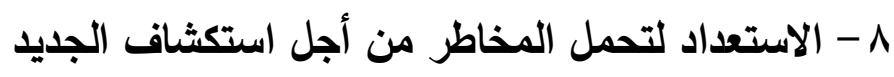

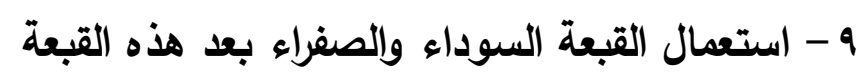

The Blue Hat القبعة الزرقاء الأزرق لون السماء التي هي فوق كل شئ آخر لذا فان القبعة الزرقاء تهتم بالتفكير والتحكم

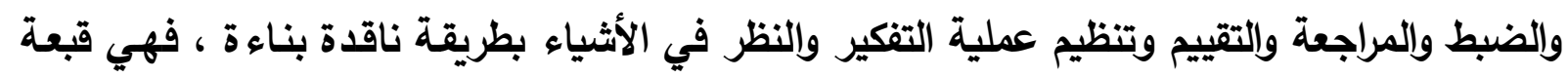

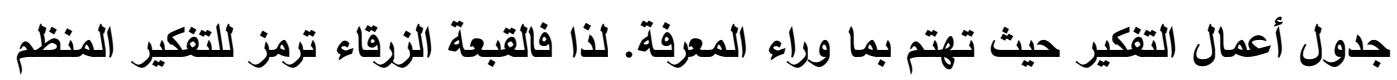
لذا فعلى كل من يرتدى هذه القبعة أن يسأل هذه الأسئلة

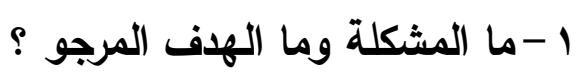

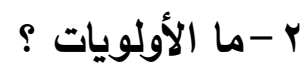

r - ما الخطة التي يمكن وضعها لضبط وتوجيه وتنظيم عملية التفكير ؟ ؛ - ما التفكير الذي يمكن حدوثه أولا وما سوف يليه

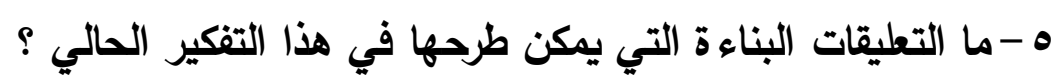

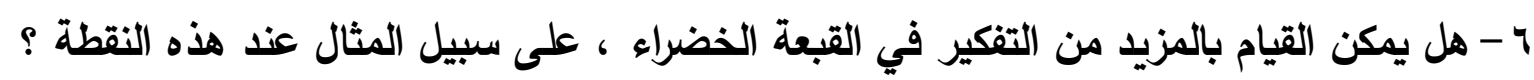

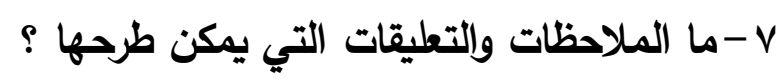
^-ماذا استفدنا حتى هذه اللحظة ؟

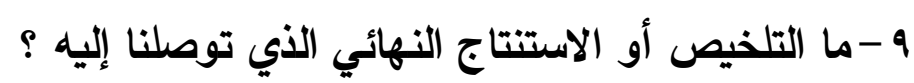
أسس استخدام القبعات على الرغم من أنـه ليس هناك تسلسل وحيد صحيح يمكن به استخدام طريقة القبعات الست للتفكير ؛ إلا أنه يوجد بعض الخطوات الإرشادية والأسس التهي يمكن إتباعها عن استخدام قبعات

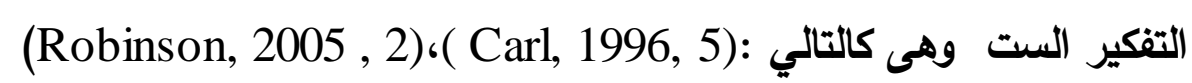
1- ايتم ارتداء قبعة واحدة في كل مرة لتعبر عن نوع التفكير المستخدم

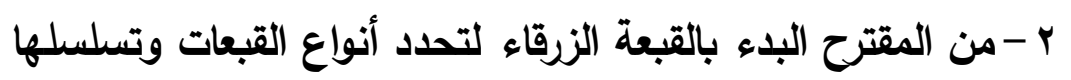


r- من الأفضل استخدام القبعة الصفراء قبل القبعة السوداء حيث إنها من الصعب أن تكون

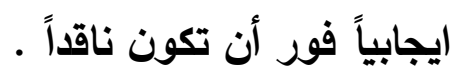

ـ - إذا كنت تعتقد في وجود مشاعر قوية نحو موضوع مـا ، فسوف تبدأ دائماً في التفكير بالقبعة الحمراء حتى تخرج هذه المشاعر خارجاً

ه - تستخدم القبعة السوداء بطريقتين : الطريقة الأولى : عند شرح نقاط الضعاء الضعف في فكرة مـا

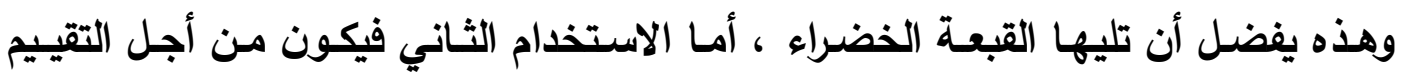

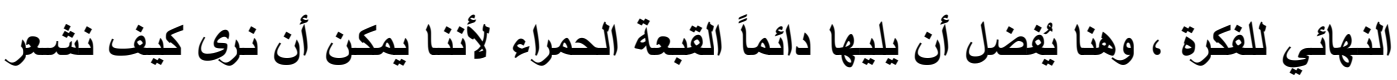

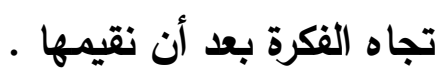
צ - إذا لم تكن هناك أي مشاعر قوية فستبأ بالقبعة البيضاء حتى تجمع المعلومات ثم القبعة

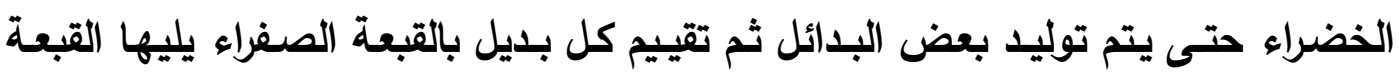

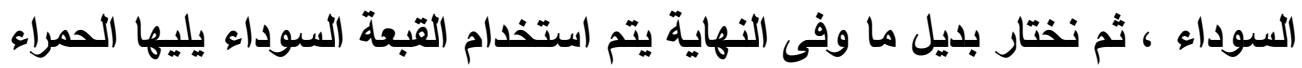

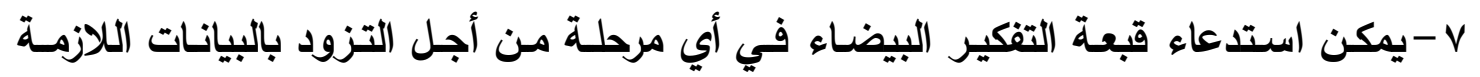

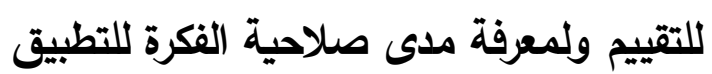
1 - عند استعمال القبعة الخضراء يفضل أن نتبعها بالصفراء أو السوداء لتقوم بدور الغربلة

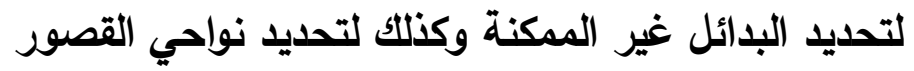
9 - من الأفضل ألا يقيد المعلم طلابه باستخدام قبعة معينة

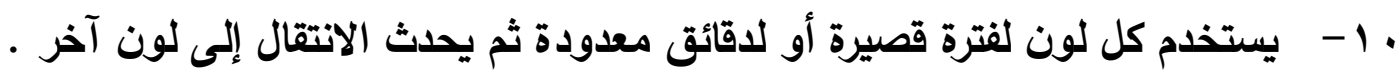

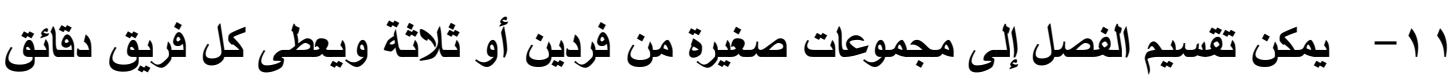
لتغيير اللون وتطوير الأفكار عن هذا اللون هيمن r ا - استخدام جميع القبعات في نفس الوقت حيث يتابع الجميع نفس الثكل في الموضوع للحصول على أقصي استخدام ممكن للتفكير المتوازي

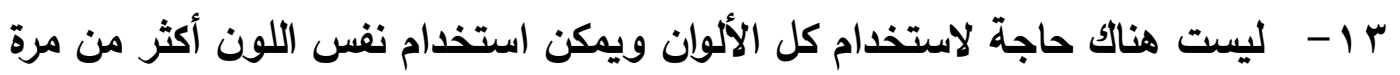

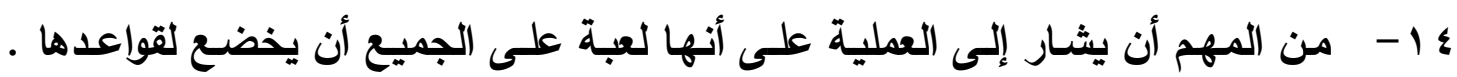

$$
\text { ويجب تسجيل النقاط على السبورة }
$$

ه - على الرغم من أهمية التحديد الواعي لنمط التفكير المستخدم إلا أنه قد يكون هناك

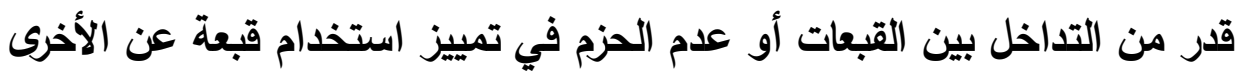

صور( أثكال ) استخدام القبعات الست للتفكير 
يمكن استخدام طريقة القبعات الست للتفكير في صورتين إما صورة فردية أو صورة جماعية كما يلي :

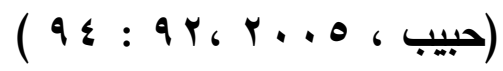

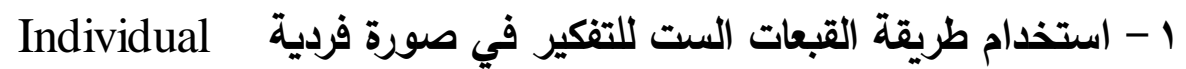

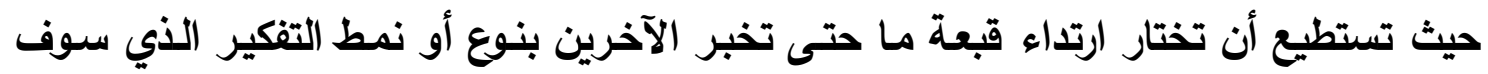

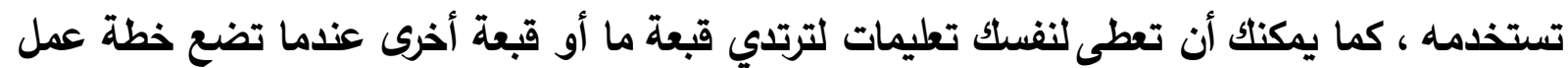

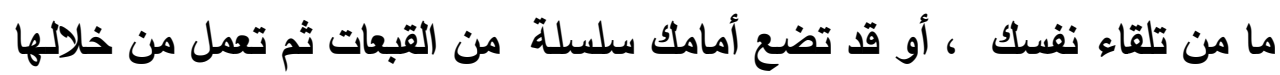

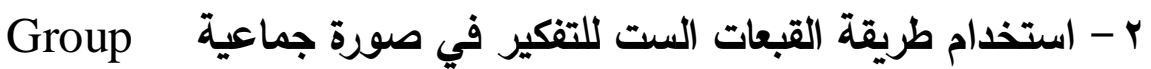

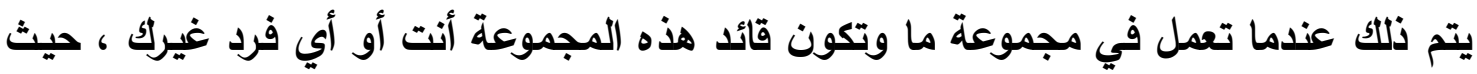

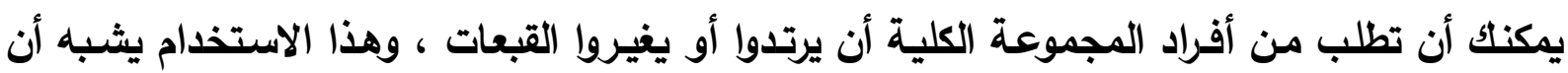
تستخدمه مع فرد آخر - باستثناء وجود مجموعة أكبر .

أهمية استخدام القبعات الست للتفكير

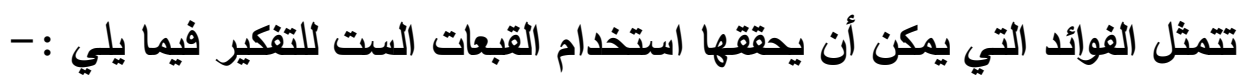

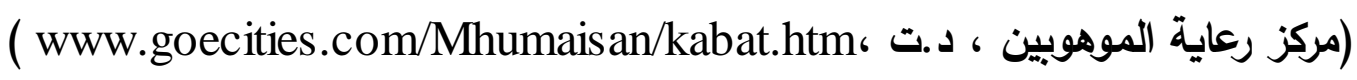
1 - تساعد طريقـة القبعات الست للتفكير على إزالة عوائق التفكير عن طريق إظهار العواطف والمشاعر كجزء صالح من التفكير ، مما يقلل من الشعور بالاضطراب وإلعجز

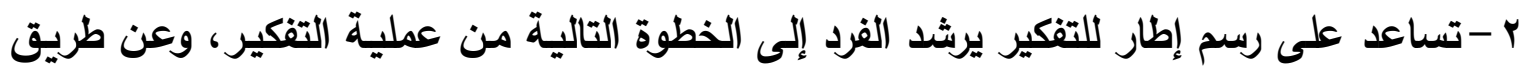

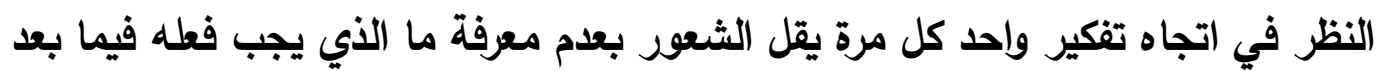

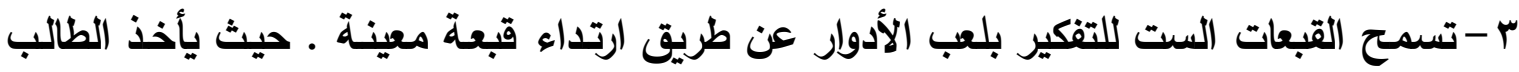

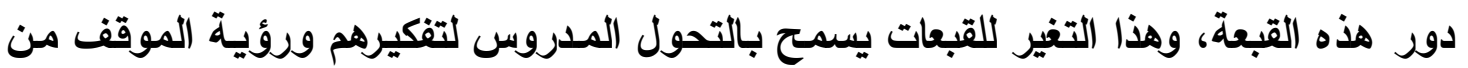
عدة جوانب ـ - يسمح ارتداء القبعات بفصل الذات عن التفكير وبالتالي يصبح الطلاب مهرة في تنفيذ أدوار التفكير المختلفة ـ ونتيجة لذلك تكون قدرات التفكير في المواقف أكثر موضوعية وشمولاًا

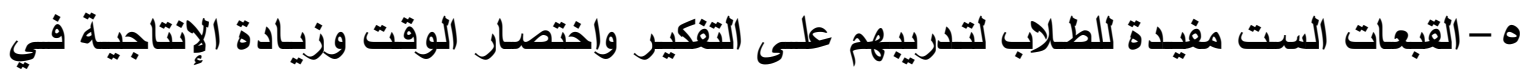
المجال الأكاديمي - (المين

ثانياً : - دوائر التعلم ( التعلم معاً ) Learning Together : (LT) 


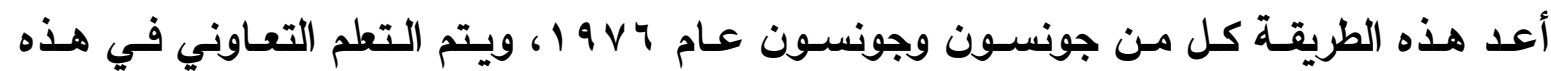

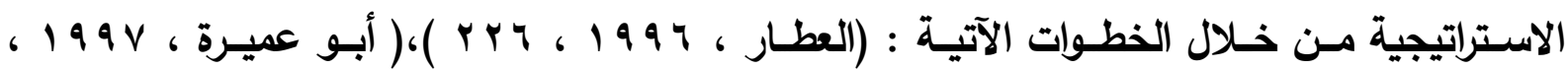

ا ب - بتم تحديد الأهداف التعليمية إجرائياً. .

r - يقسم المعلم التلاميذ إلى مجموعات صغيرة متجانسة يتراوح عددها مابين ( r - يقسم كل درس إلى مهام فرعية وتقدم للتلاميذ فى صورة أوراق عمل وعلى التلاميذ تنفيذ هذه مداته

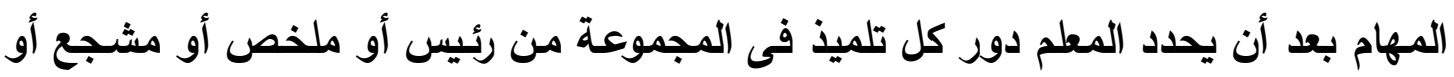

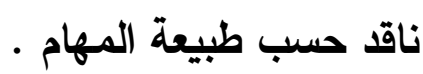
ع - يحث المعلم تلاميذ كل مجموعة على المناقثة الجماعية ، والتفاعل مـع بعضهم دون حدوث شغب أو ضجيج داخل الفصل .

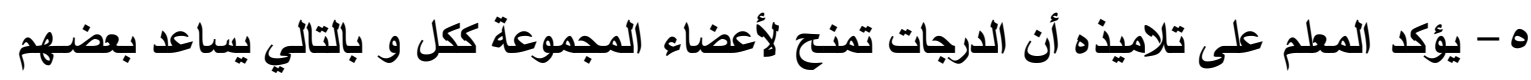

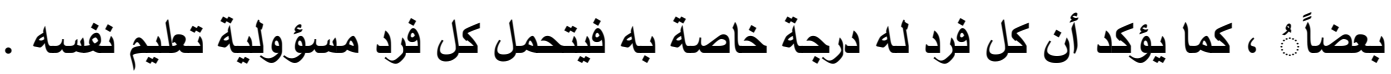

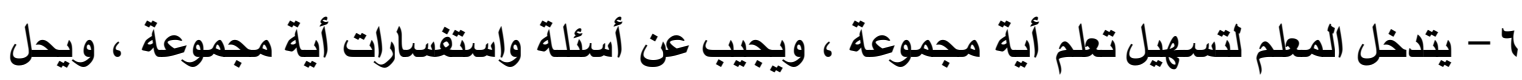

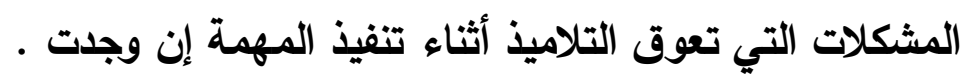
V - تعرض كل مجموعة التقرير الذي أعدته أمام المجموعات الأخرى ، ويطلب المعلم من كل التهل

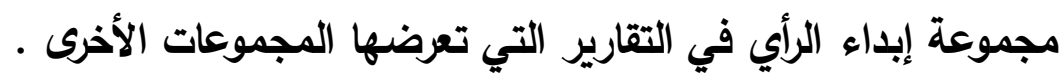

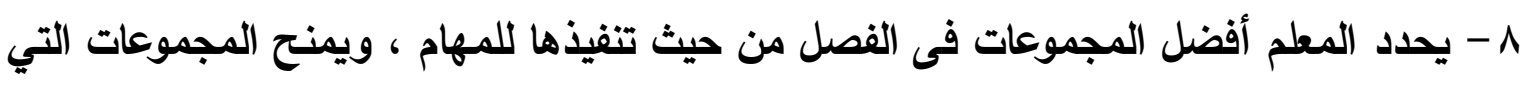
تحصل على أعلى الارجات جوائز مادية أو معنوية .

- مزايا تدريس التعبير الكتابي باستخدام طرق التعم التعاونيـ يؤكد حازم قاسم أن هناك بعض المميزات التي يحققها تدريس التعبير الكتابي باستخدام التعلم

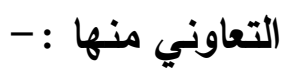

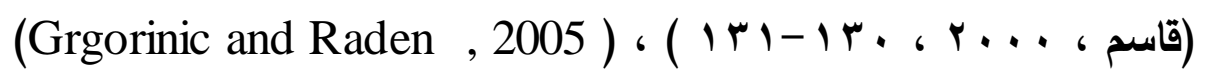

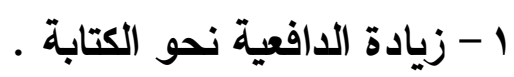

r - تحسن مستوى التلاميذ في المهارات المتعقة بالأفكار .

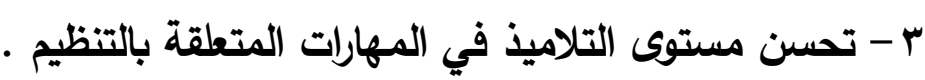

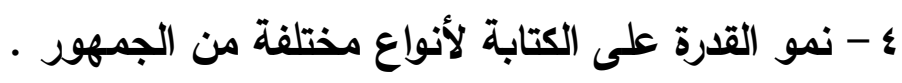

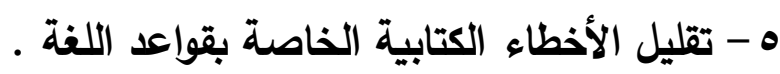
צ - نمو القدرة على الكتابة من الناحية الكمية . 
V - زيادة الاتجاهات الكتابية نحو الكتابة .

^- نمو بعض مهارات الاستماع وإلحديث وإلقراءة فى ظل نمو مهارات الكاتهات الكتابة . 9 - تخفيف عبء تصحيح كتابات التلاميذ عن المعلمين . ـ 1 - تغيير نظرة التلاميذ للكتابة ؛ لتصبح عملية تفاعلية وشكل من أشكال التواصل اللغوي .

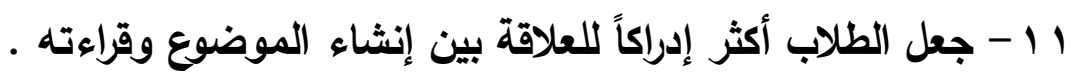
r r I تشجيع الفردية لاى الطلاب من خلال الحوار . r 1 - نظرة الطلاب إلى أفكارهم بأنها لها قيمة كبيرة ؛ لأنها تثكلت عن طرل لهوريق مجموعة وليس فرد واحد .

فرض الدراسة

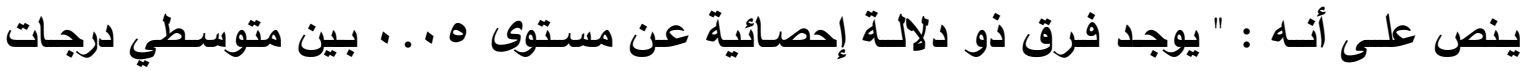

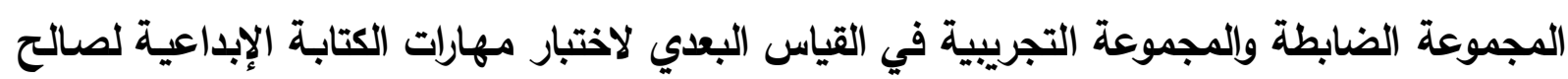

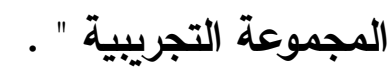
وقد قسمت الباحثة الفرض السابق إلى الفروض الفرعية التالية : -

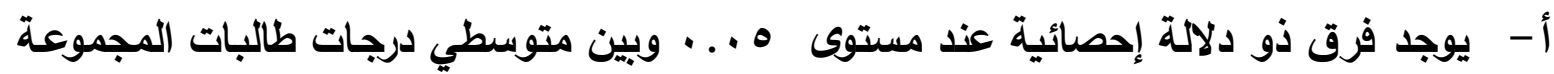

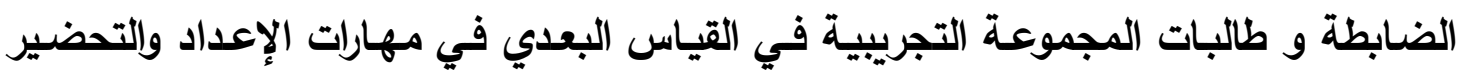
( ما قبل الكتابة ) لصالح طالبات المجموعة التجريبية .

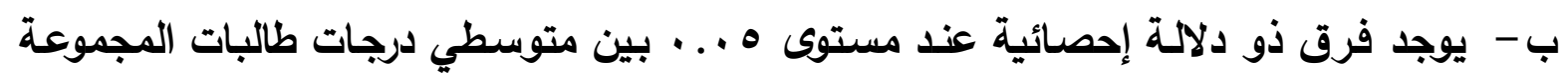
الضابطة و طالبات المجموعة التجريبية في القياس البعدي في مهارات التأليف والإنتاج لصاتح طالبات المجموعة التجريبية .

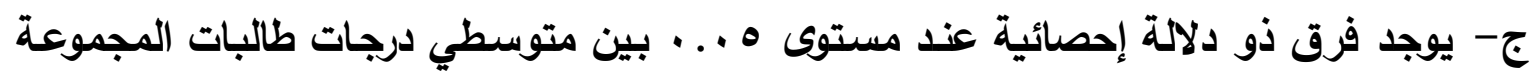
الضابطة و طالبات المجموعة التجريبية في القياس البعدي مهارات المراجعة والتعديل لصالح

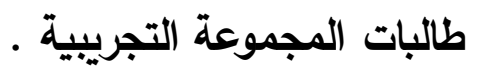
د - يوجد فرق ذو دلالة إحصائية عند مستوى ه ه . . بين متوسطي درجات طالبات المجموعة الضابطة وطالبات المجموعة التجريبية في القياس البعدي لاختبار مهارات الكتابة الإبداعية ككل . 
1 - إعداد قائمة بمهارات الكتابة الإبداعية في مجال المقال الأدبي المناسبة لعينة الدراسة ، وذلك من

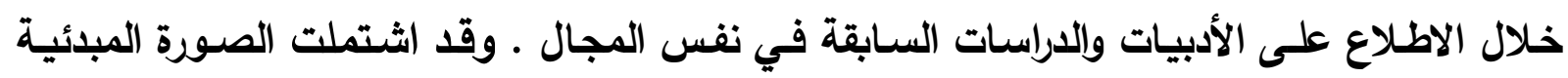

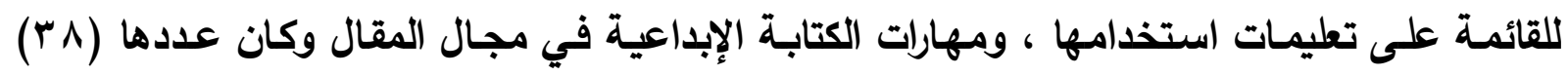
مهارة . r - عرض القائمة في صورتها المبائية على مجموعة من المحكمين من أساتذة ومدرسين بقسم

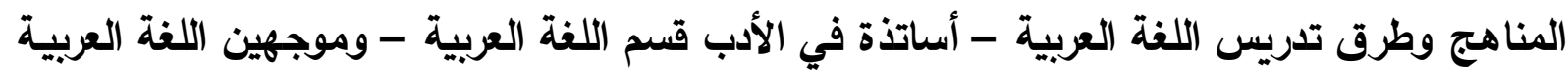

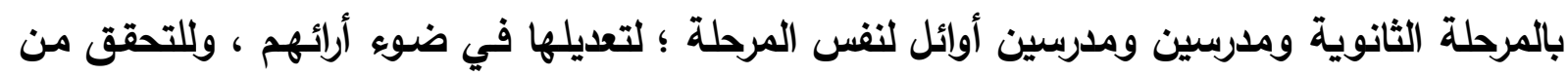

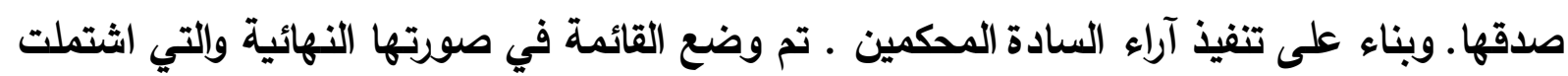

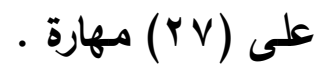
r - إعداد برنامج الدراسة وتحديد جوانبه ومقوماته فيما يلي : -

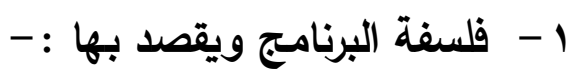
أ - أ - تحديد ماهية البرنامج.

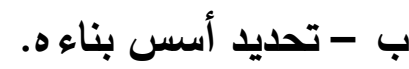

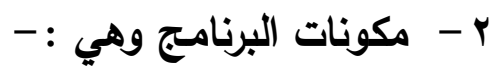
أ - أهداف تدريس التعبير في الصف الثان الثي الثاني الثانوي.

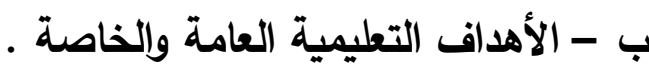
ج - المحتوى الاراسي. د - الاستراتيجية المقترحة للتدريس ، وإجراءات استخدامها. هـ - الوسائل والأنشطة التعليمية. و - الأساليب التقويمية المتبعة.

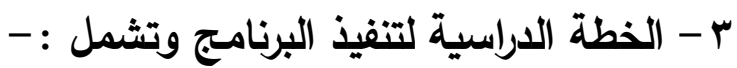
ب - القبائم بالتدريس. أ - مدة التدريس.

وقد تحدد محتوى برنامج الاراسة الحالية في بعض موضوعات التعبير التي وقع اختيار الباحثة

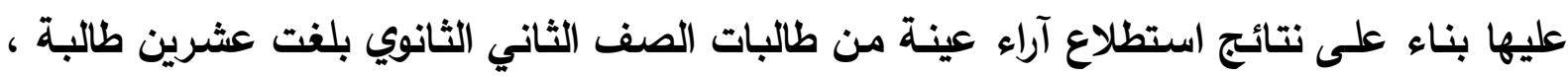

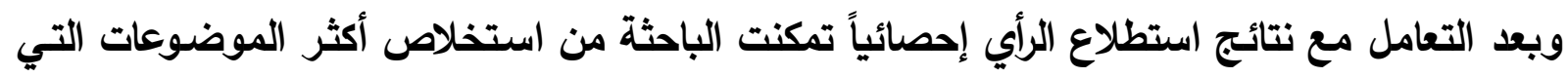

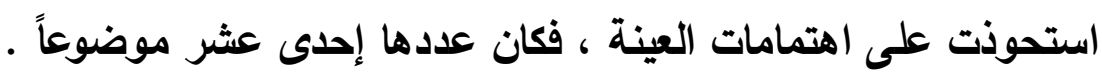

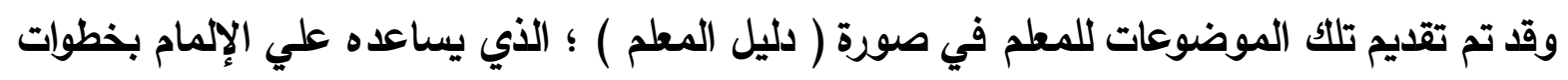

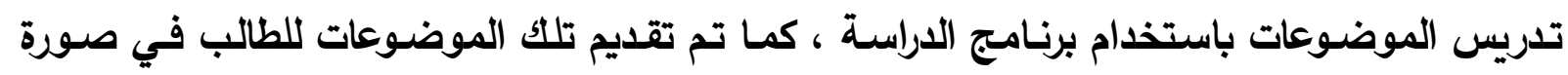


( أوراق عمل للطالب ) ؛ والتي تساعده علي متابعة المطلم أثناء تدريس الموضوعات ، والإجابة علي

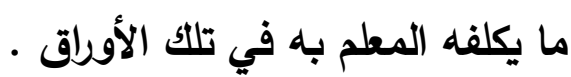
؟ - إعداد اختبار في مهارات الكتابة الإبداعية في مجال المقال ؛ لتقييم اكتساب مهارات المقال للدى

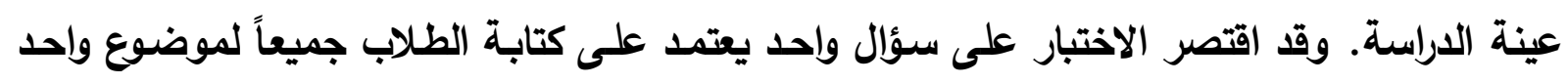
لسبين :

ا ـ تجنباً لتلخل وتأثير عامل اختلاف الموضوع على كتابة الطلاب.

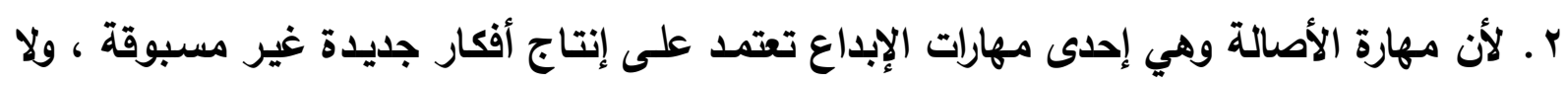

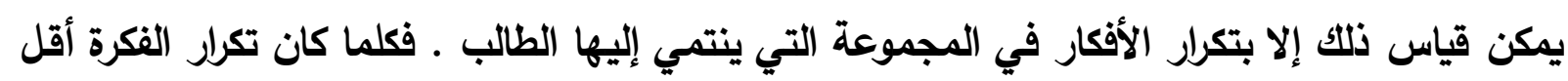
كان ذلك دليل على أصالتها . وللتأكد من ذلك تم عرض الاختبار من صورته المبائية على مجموعة من المحكمين لإبداء رأيهم

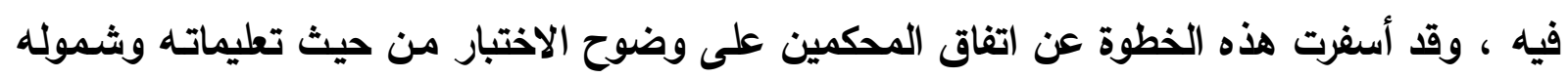

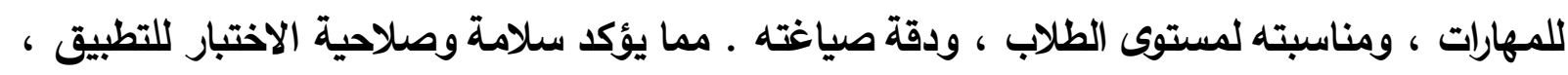

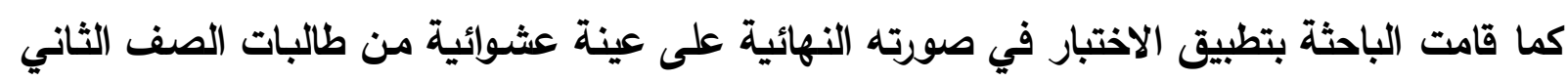

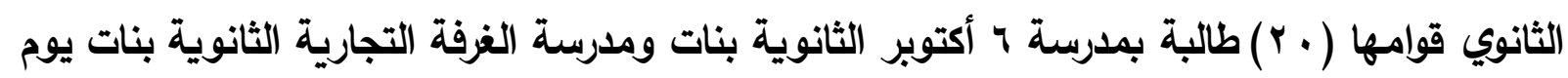

$$
\text { }
$$

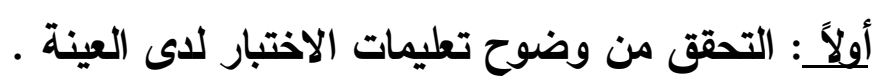

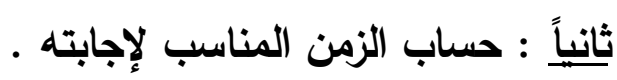

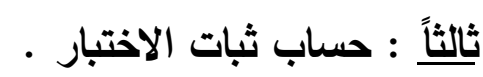

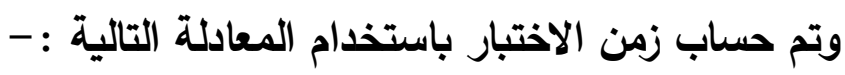

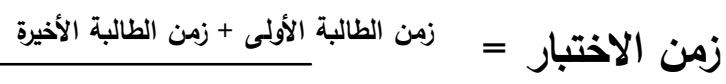

$r$

وبذلك كان الزمن المناسب لإجابة الاختبار (00) دقيقة .

وقد استخدمت الباحثة معامل ألفا لحساب ثبات الاختبار فكانت قيمته V V . . وهي قيمة يمكن الوثوق

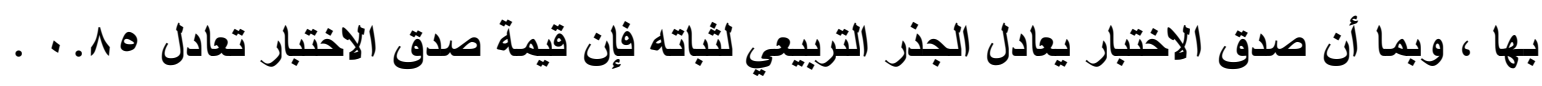

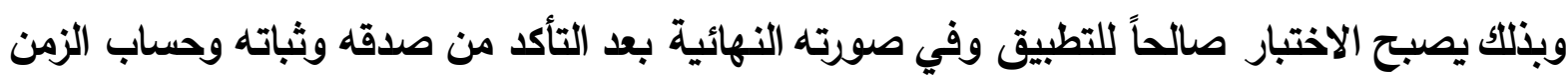

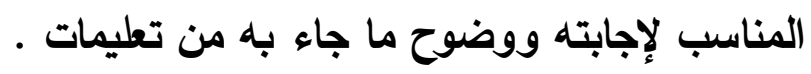
ه -اختيار عينة عشوائية وتقسيمها إلى مجموعتين متكافئتين ( ضابطة وتجريبية ) . 
حيث اختارت الباحثة عينة عشـائية من طالبات الصف الثاني الثانوي بمدرسـة ج أكتوبر الثانويـة

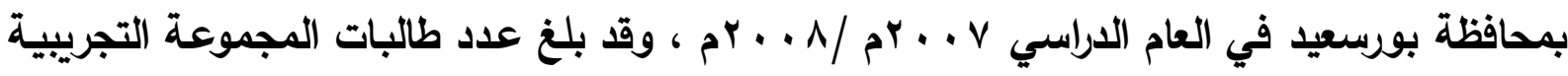

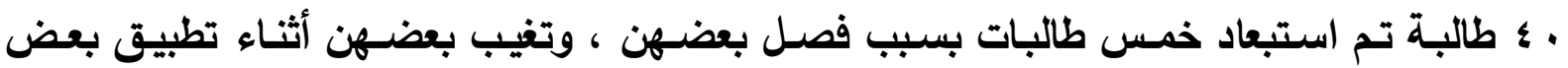

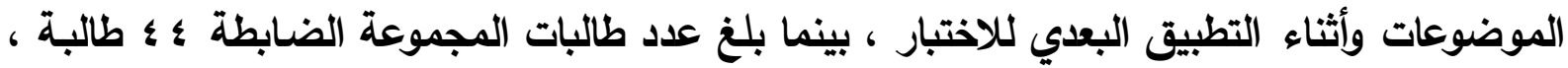

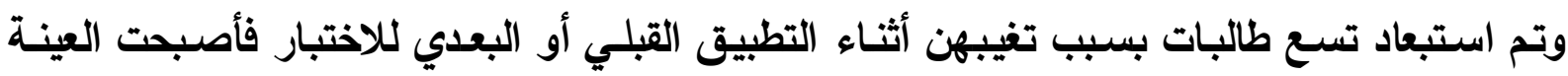
الفعلية • V طالبة .

7 - تطبيق الاختبار قبلياً على عينة الدراسة للتأكد من تكافؤ المجموعتين .

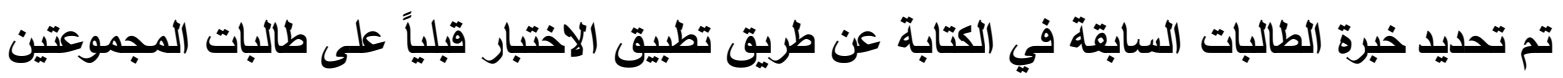

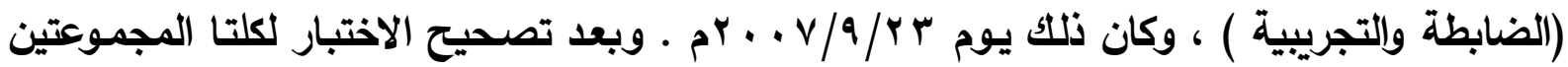

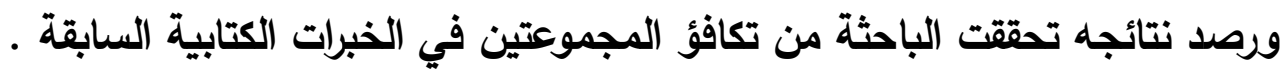

V - تدريس موضوعات البرنامج وفق الاستراتيجية المقترحة للمجموعة التجريبية ، في حين تدرس

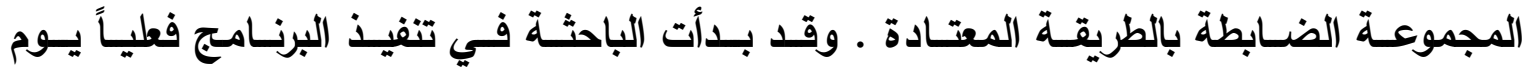

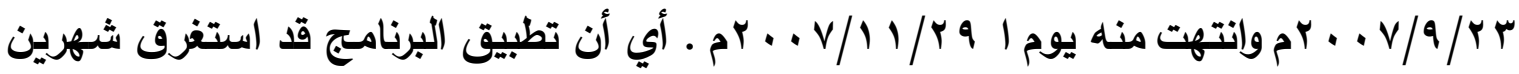
وسبعة أيام تقريباً .

^ - تطبيق الاختبار بعدياً على عينة الاراسة . حيث قامت الباحثة بتطبيق اختبار الدراسة المعد

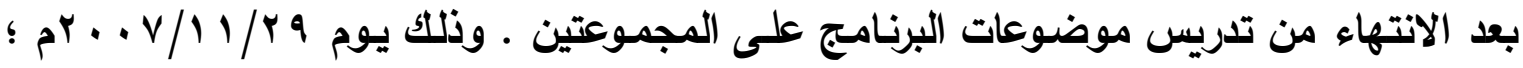

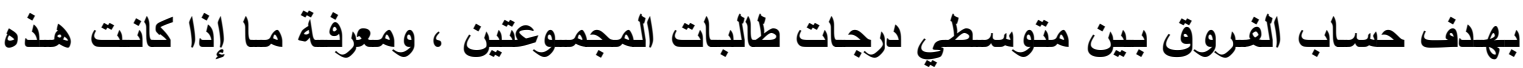

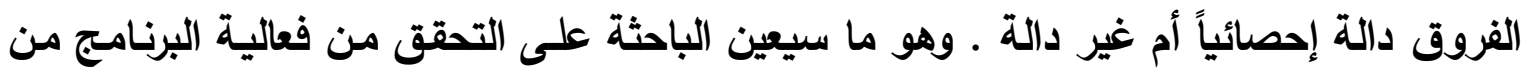
عدم فعاليته .

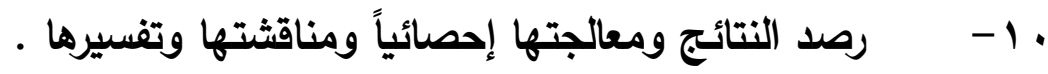
وفيما يلي عرض للنتائج الإحصائية لكل فرض من الفروض السابقة : -

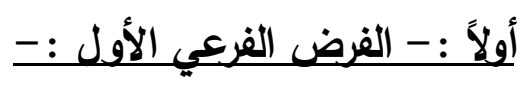

وينص على أنه " يوجد فرق ذو دلالة إحصائية عند مستوى ه ه .. . بين متوسطي درجات طالبات

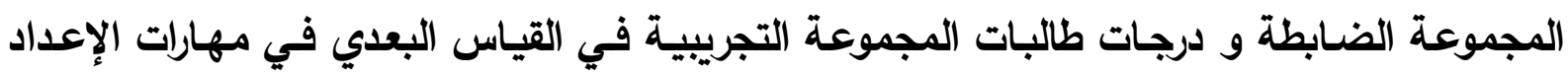
والتحضير (ما قبل الكتابة ) لصالح طالبات المجموعة التجريبية " 


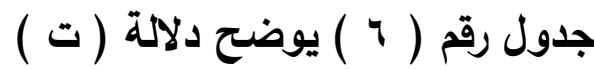

لارجات طالبات المجموعتين الضابطة والتجريبية في القياس البعدي لمهارات ما قبل الكتابة

\begin{tabular}{|c|c|c|c|c|c|c|c|c|}
\hline مستوى الدلالة & الدلالة & المحسوبة & د. د. & $\varepsilon$ & r & $\dot{ن}$ & المجموعة & مهارات \\
\hline \multirow[t]{2}{*}{$\ldots 1$} & دالة & $r \cdot . \wedge$ & 71 & ..vrq & $1.0 V 1$ & ro & الضابطة & \multirow{2}{*}{ الإعداد والتــــير (مـابة ) } \\
\hline & إحصائياً & & & $1.7 \pi$ & $1 . . \wedge \wedge 7$ & ro & التجريبية & \\
\hline
\end{tabular}

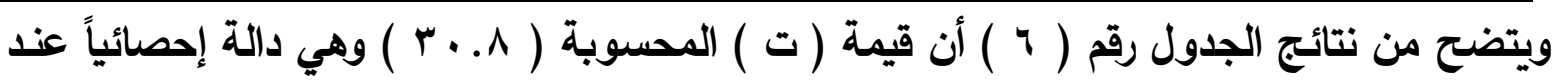

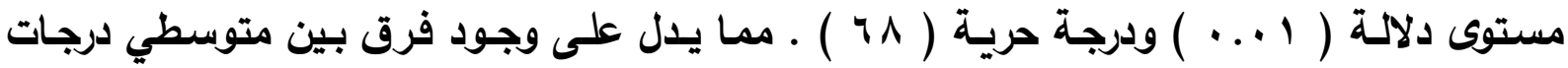

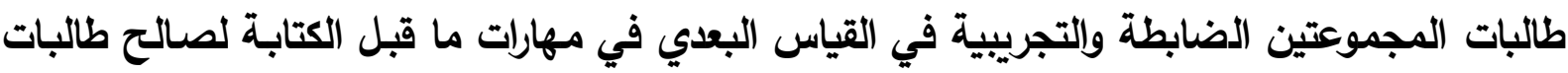

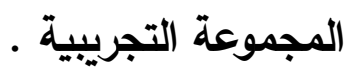

\section{ثانياً : الفرض الفرعي الثاني :}

وينص على أنه " يوجد فرق ذو دلالة إحصائية عند مستوى ه ه. . . بين متوسطي درجات طالبات

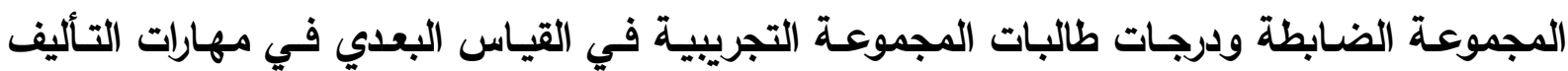
والإنتاج لصالح طالبات المجموعة التجريبية " .

$$
\text { جدول رقم ( V ) يوضح دلالة (تات ) }
$$

لارجات طالبات المجموعتين الضابطة والتجريبية في القياس البعدي لمهارات مرحلة التأليف والإنتاج

\begin{tabular}{|c|c|c|c|c|c|c|c|c|}
\hline مستوى الدلالة & الدلالة & المحسوبة & ح.د & $\varepsilon$ & $r$ & ن & المجموعة & مهارات \\
\hline$\ldots 1$ & دالة & IrV..r & 91 &. $.5 \cdot 9$ & $1 . r \leqslant r$ & ro & الضابطة & الإنتـــاج \\
\hline & إحصائياً & & & 1.rrr & rq.1 rq & ro & التجريبية & \\
\hline
\end{tabular}

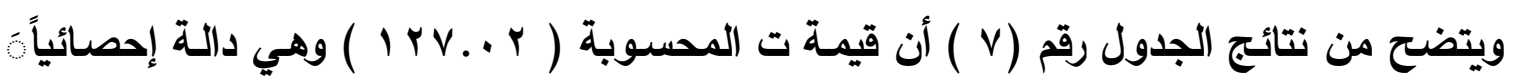

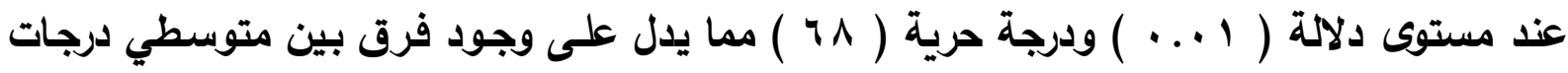

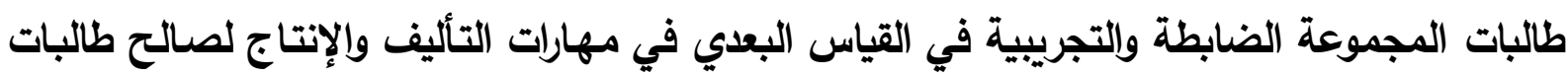
المجموعة التجريبية 
تالثاً : - الفرض الفرعي الثالث :

وينص على أنـه " يوجد فرق ذو دلالـة إحصائية عند مستوى ه ه. . . بين متوسطي درجات

طالبات المجموعـة الضـابطة ودرجـات طالبات المجموعـة التجريبية في القيـاس البعدي في مهارات المراجعة والتعديل لصالح طالبات المجموعة التجريبية".

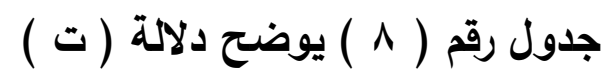

لارجات طالبات المجموعتين الضابطة والتجريبية في القياس البعدي

لمهارات المراجعة والتعديل

\begin{tabular}{|c|c|c|c|c|c|c|c|c|}
\hline مستوى الدلالة & الدلالة & تحسوبة & $\tau \cdot د$ & $\varepsilon$ & p & ن & المجموعة & مهارات \\
\hline$\ldots 1$ & دالة & $\varepsilon 7 . V$ & $7 \wedge$ &..$\varepsilon r \varepsilon$ & I. . . . & ro & الضابطة & المراجعة \\
\hline & إحصائياً & & & .91. & q.v & ro & التجريبية & والتعديل \\
\hline
\end{tabular}

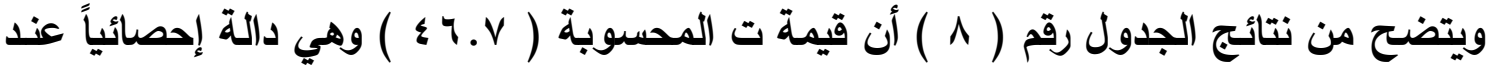

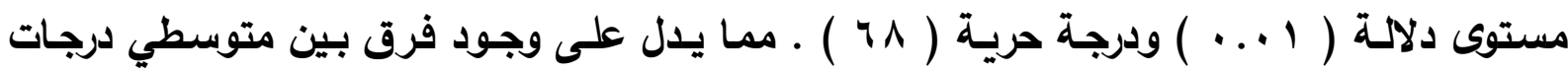
طالبات المجموعتين الضابطة والتجريبية في القياس البعدي في مهارات المراجعة والتعديل .

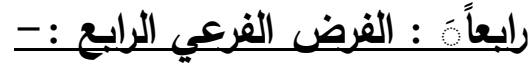

وينص على أنه " يوجد فرق ذو دلالة إحصائية عند مستوى ه ه . . بين متوسطي درجات طالبات

المجموعة الضابطة ودرجات طالبات المجموعة التجريبية في القياس البعدي لاختبار مهارات الكتابة

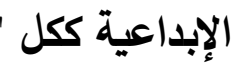

$$
\text { جدول رقم ( } 9 \text { ) يوضتح دلالة ( ت ) }
$$

لارجات طالبات المجموعتين الضابطة والتجريبية

\begin{tabular}{|c|c|c|c|c|c|c|c|c|}
\hline الدلالة & الدلالة & المحسوبة & د. د. & $\varepsilon$ & p & ن & المجموعة & مهارات \\
\hline \multirow[t]{2}{*}{$\ldots 1$} & دالة & rVV.r & 71 &..$\wedge 94$ & $\leq .11 \leqslant$ & ro & الضابطة & كتابـــــــــان \\
\hline & إحصائياً & & & . $r \wedge q$ & $\leq q . \vee 1 \leqslant$ & ro & التجريبية & \\
\hline
\end{tabular}

في القياس البعدي لاختبار مهارات الكتابة الإبداعية كل 
ويتضح من نتائج الجدول رقم ( 9 ) أن قيمة ت المحسوبة ( rVV.r ) وهي دالة إحصائياً

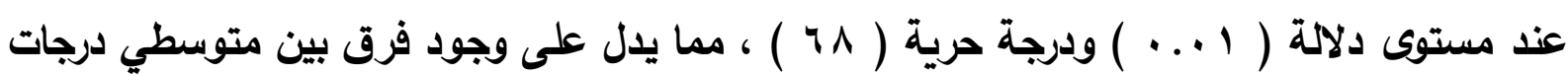

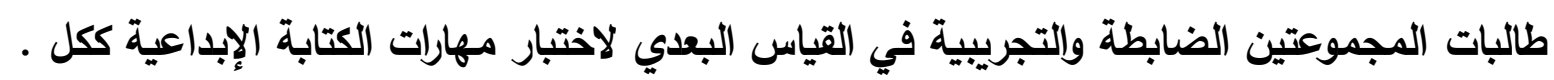

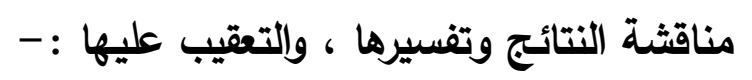

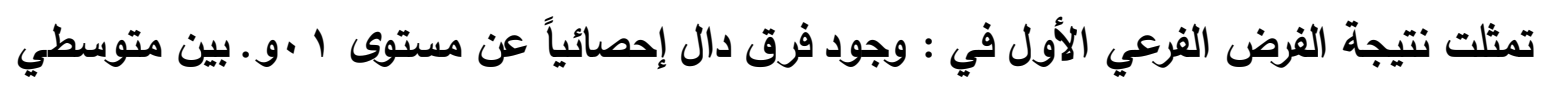

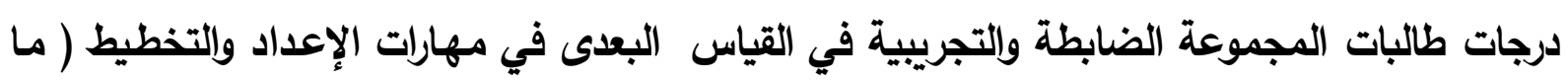
قبل الكتابة ) لصالح طالبات المجموعة التجريبية .

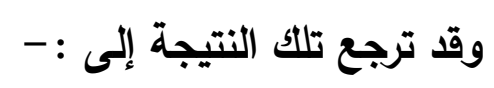

1 - أن اتباع الطالبات خطوات التفكير باستخدام طريقة القبعات الست للتفكير قد ساعدتهن على

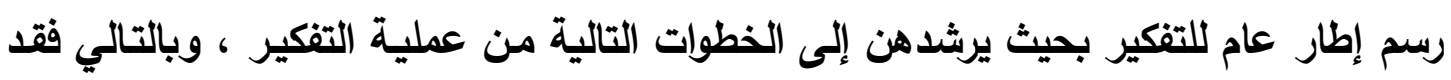

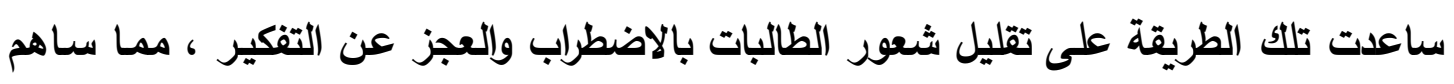

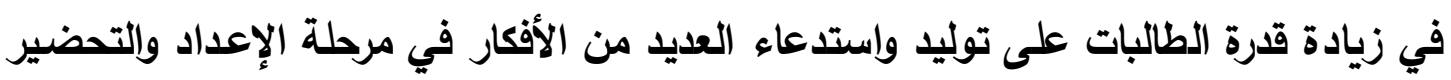

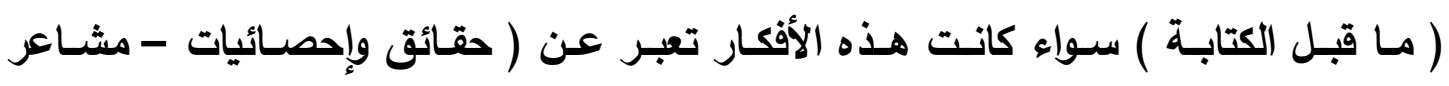
وأحاسيس - إيجابيات ومقترحات - سلبيات ومحاذير - أفكار إبداعية )

r - أن تعاون الطالبات في مناقثة وعرض أراء ووجهات نظر متعددة وبناءهن على تلك الآراء ،

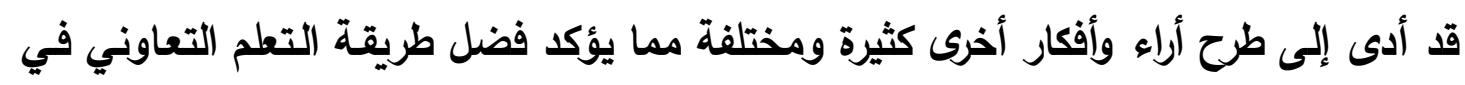

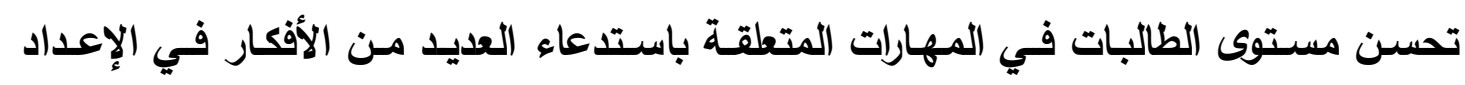

$$
\text { والتحضير ( ما قبل الكتابة ) . }
$$

r - أن تحرر الطالبات في جلوسهن وفى طرحهن للأفكار بفضل طريقة التعلم التعاوني - والتي

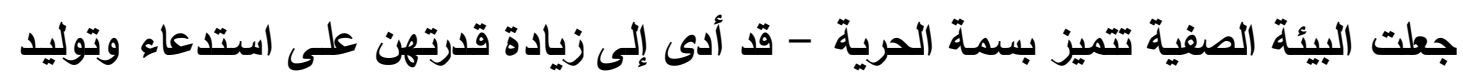

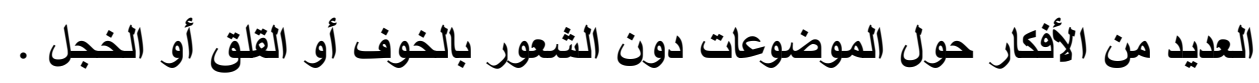

تمثلت نتيجـة الفرض الفرعي الثاني في : وجود فرق دال إحصائياً عند مستوى 1 .و. بين الفين

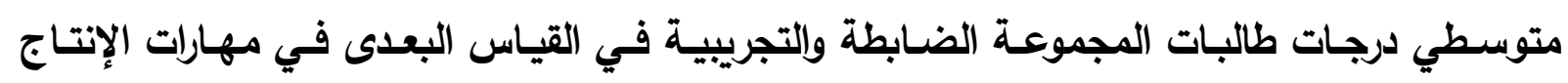
والتأليف لصالح طالبات المجموعة التجريبية . 


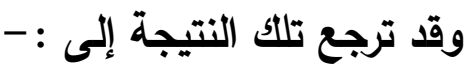

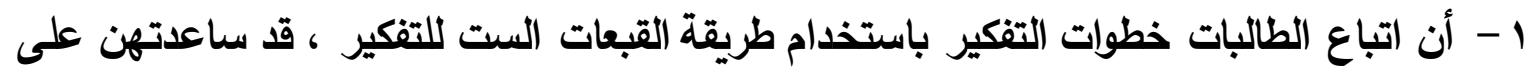
إنتاج وتكوين أفكار أصيلة وجديدة وذلكك بفضل تلدربيهن على التفكير باستخدام ( القبعة التهات الخضراء ) والتي جاءت أفكارها كتناج تراكمي للتفكير بالقبعات الأخرى .

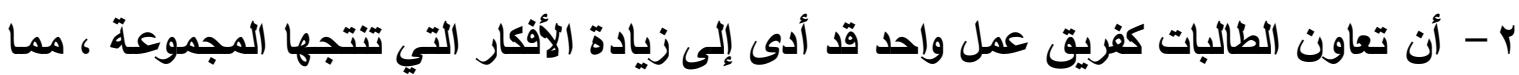

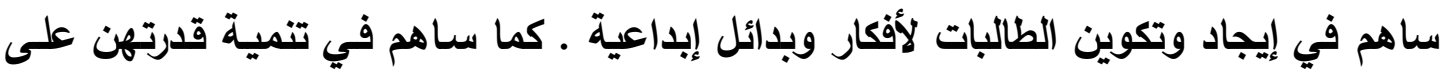
حل المشكلات وإطلاق قدراتهن الإبداعية .

تمثلت نتيجـة الفرض الفرعي الثالث في : وجـود فرق دال إحصـائياً عند مستوى 1 .و. بين متوسطي درجات طالبات المجموعة الضـابطة والتجريبيـة في القياس البعدى في مهارات المراجعة دئة والتعديل لصالح طالبات المجموعة التجريبية .

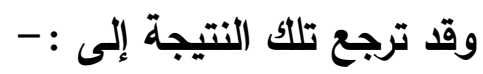
1 - أن تعاون الطالبات في العـل كفريق واحدا ، ومشـاركتهن في أنشطة البرنامج المتمثلـة في

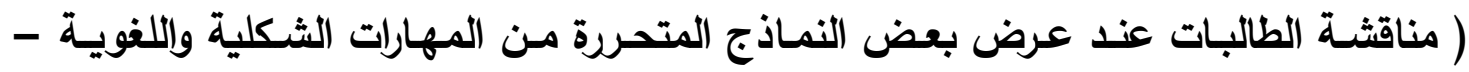

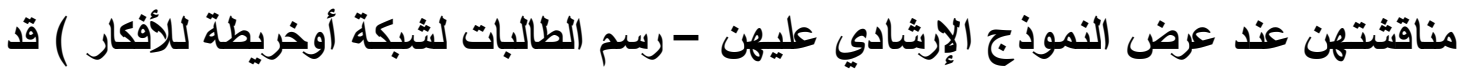

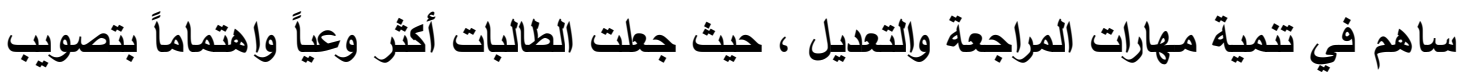

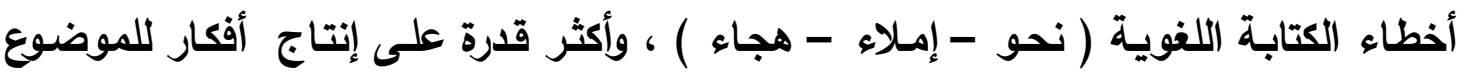
وترتيبها ترتيباً مقنعاً بما يحقق السهولة والسلاسة في الانتقال من فكرة إلى أخرى .

تمثلت نتيجة الفرض الفرعي الرابع في : وجود فرق دال إحصائياً عند مستوى 1 ـو · بين

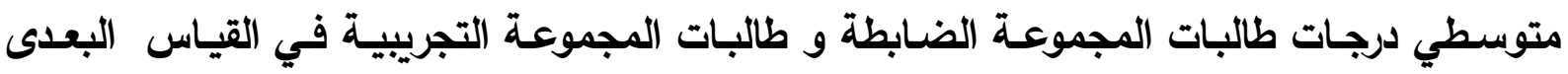
لاختبار الكتابة الإبداعية ككل .

$$
\text { وقد ترجع تلك النتيجة إلى : - الإبه كلئ }
$$

1 - تضافر كل من طريقتي القبعات الست للتفكير والتعطم التعاوني في تنمية مهارات الكتابة

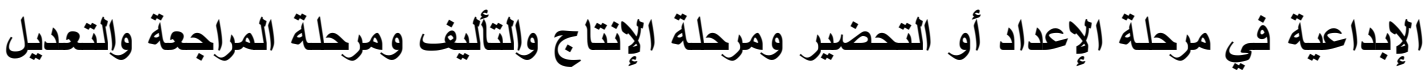

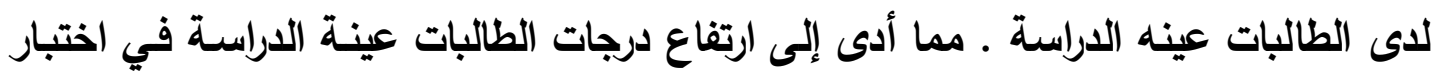

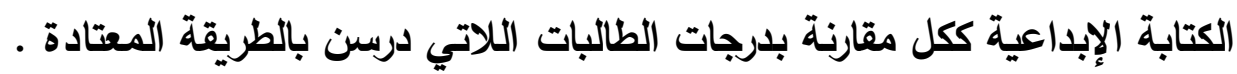

لذا فإن نتائج الدراسة الحالية قد جاءت تعزيزاً لنتائج العديد من الدراسات والبحوث منها : - 


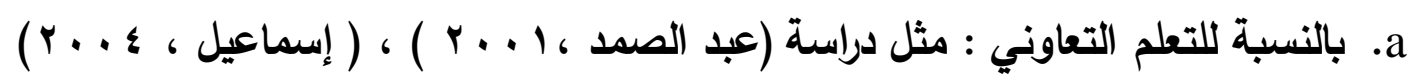

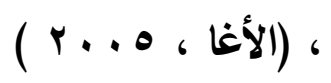

وفى حدود علم الباحثة فإنـه لا توجد دراسـة - أُجريت من قبل - أكلت فعالية استخدام طريقة

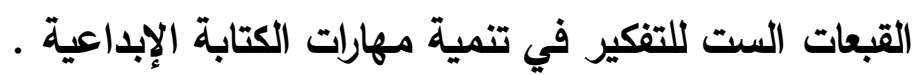

$$
\begin{aligned}
& \text { ـ } 1 \text { - تقديم التوصيات والمقترحات : } \\
& \text { أولاًا : التوصيات }
\end{aligned}
$$

بناءً على ما أسفرت عنه الاراسة نظرياً وتطبيقياً ، وفي ضوء ما تم التوصل إليه من نتائج .

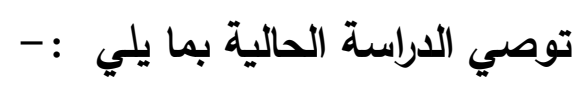

• أن يولي معلمو اللفة العربية عنايتهم باستخدام طرق واستراتيجيات تعليم التفكير - مثل طريقة

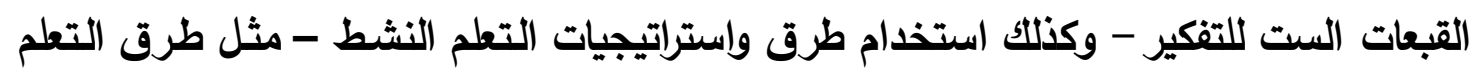

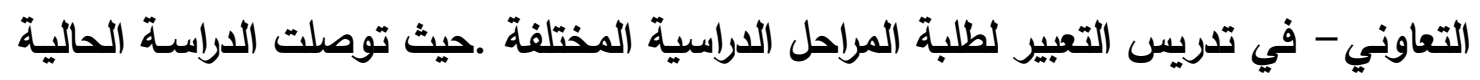
إلى فعالية الإستراتيجية المقترحة في تنمية مهارات الكتابة الإبداعية في مجال المقال

• أن يولي معلمو اللفة العربية عنايتهم بالتعبير الكتابي الإبداعي لطلبة كل المراحل الدراسية ؛ لما له من أهمية عظيمة في الكثف عن المواهب وصقلها ، وتذوق الأعمال الأدبية ، تحفيز الخيال ، تحقيق المتعة والتسلية .

ثانيا : المقترحات

تمثل الاراسـة الحالية نقطة انطلاق لإجراء دراسـات أخرى ترتبط بمجال تعليم اللغة العربية وتنمية

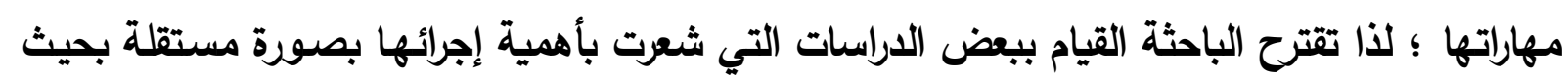

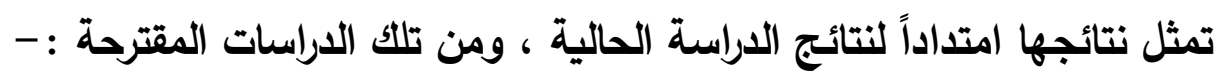

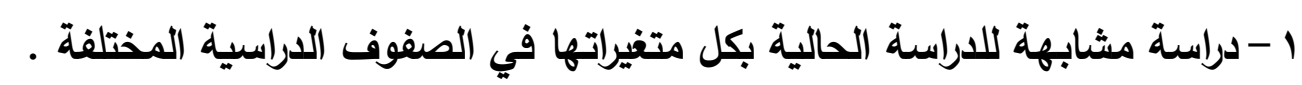

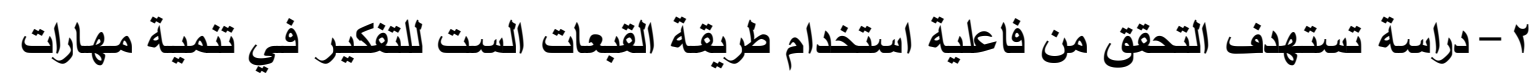

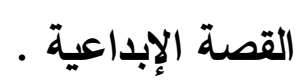

r - دراسة تستهاف التحقق من فاعلية استخدام طريقة القبعات الست للتفكير في تنمية مهارات القراءة الناقدة والاتجاه نحو المادة . 
ع - دراسة تستهدف إجراء مفاضلة تجريبية بين استخدام طريقة القبعات الست للتفكير وطريقة

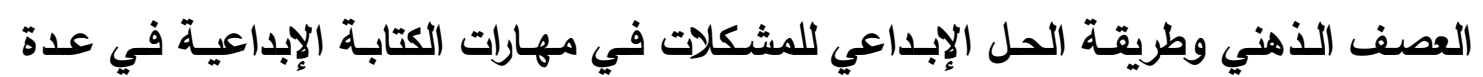
مجالات ( كالقصة والمقال والمسرحية ) في المرحلة الثانوية .

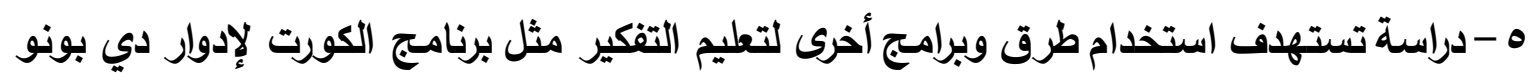

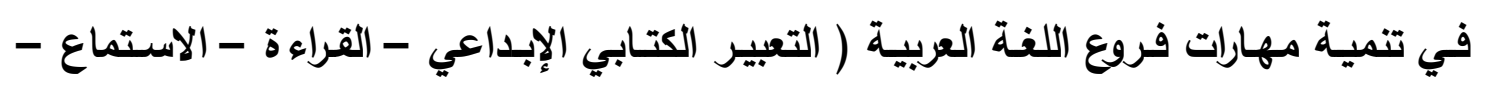
(التحدث ) 


\section{المراجع}

أولاًا : المراجع العربية

- أبو سماحة ، كمال كامل (9 194 ( ) : الإبداع والتطوير مفاهيم أساسية ، مجلة كلية التربية

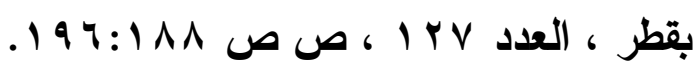
- أبو عميرة ، محبات (9 9 ( 9 ) : تجريب استخدام استراتيجيتي التعلم التعاوني الجمعي و التعلم

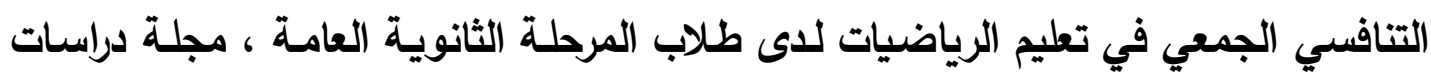

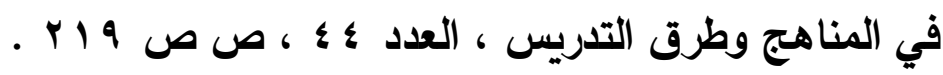

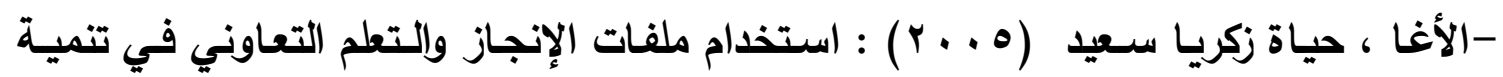
مهارات التعبير الكتابي الإبداعي لاى طالبات الصف العاشر بفلسطين ، رسالة دكتوراه غير

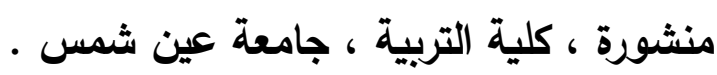

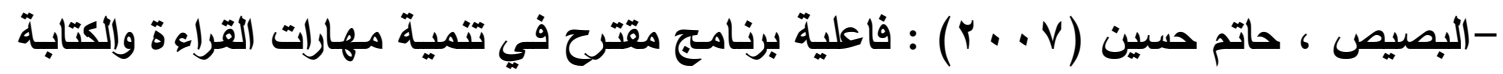

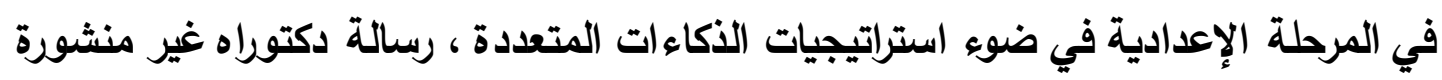
، معهد الاراسات والبحوث التربوية ، جامعة القاهرة .

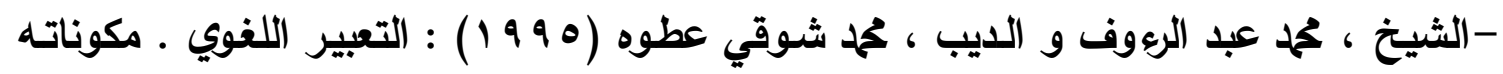

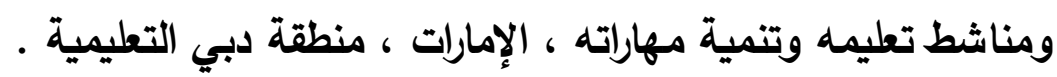

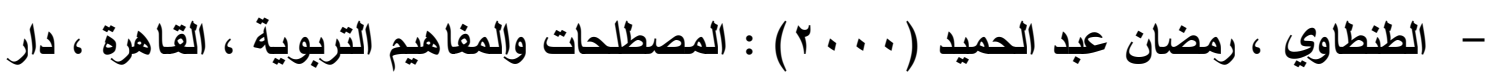
النهضة العربية .

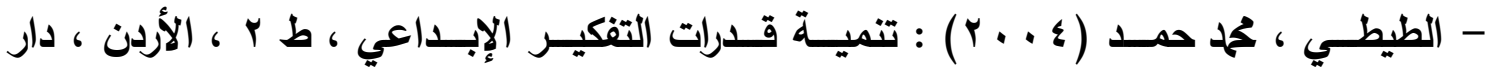
الميسرة .

- - - العطار ، محمد عبد الروف (

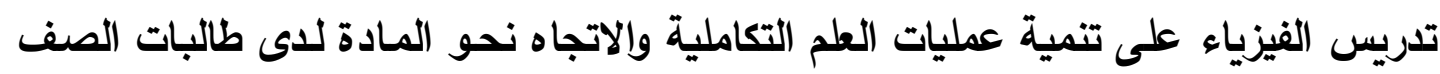

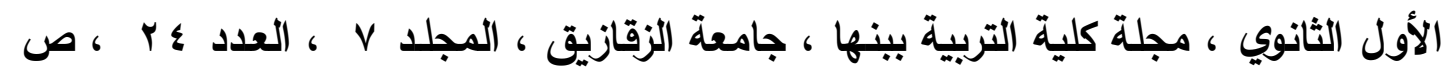
• ror:riv

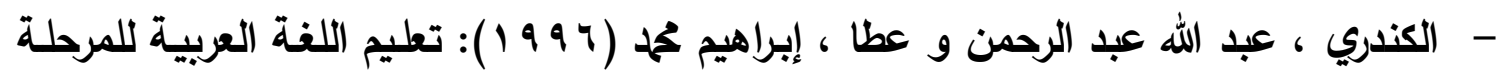

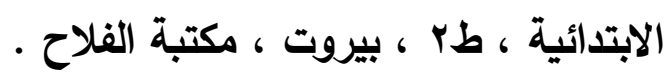

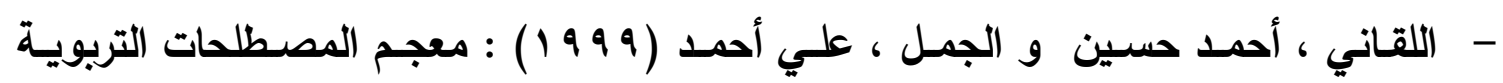

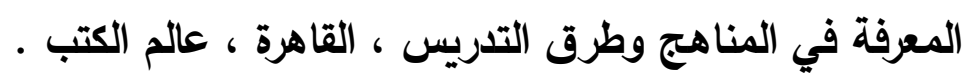


- الملأ ، بدرية سعيد و المطاوعة ، فاطمة تحمل (99V 1 ) ) دراسة لمجموعة من العوامل التي

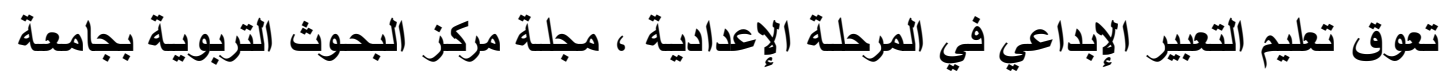

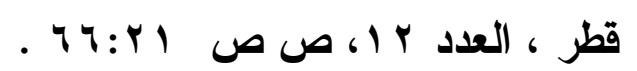

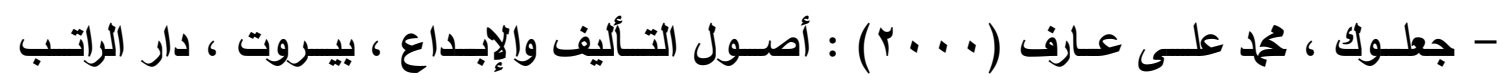
الجامعية .

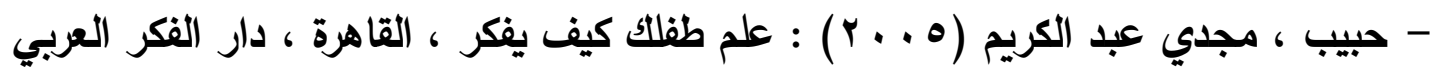

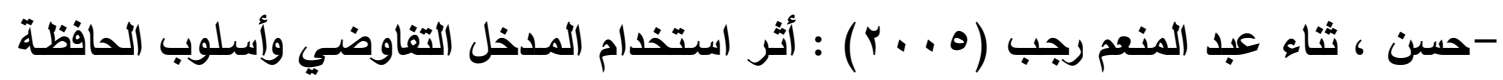

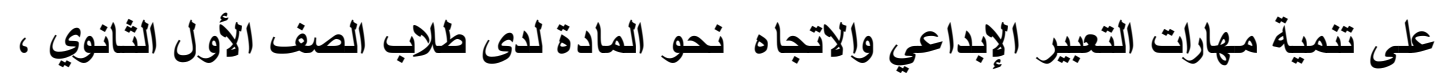

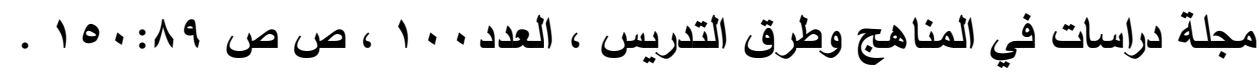

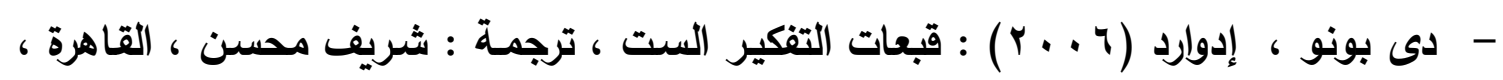

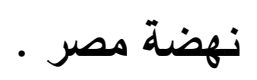

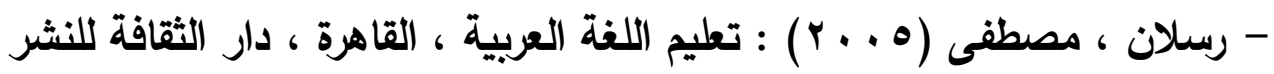

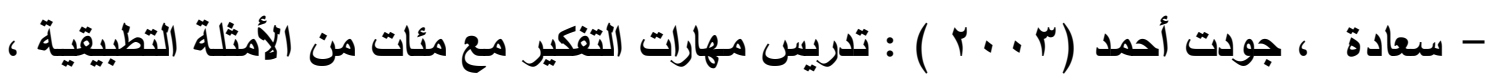

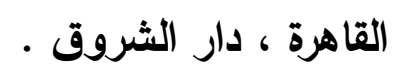

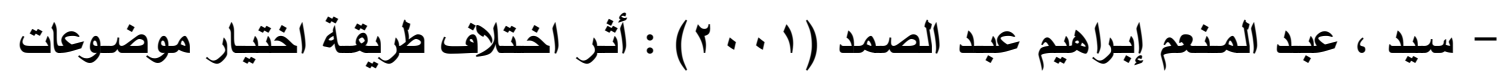

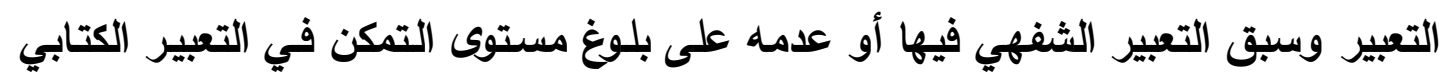

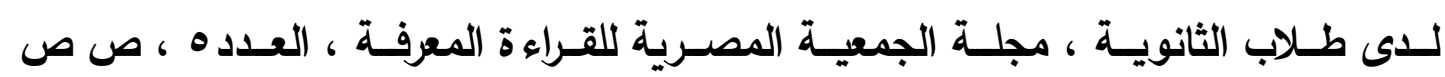
. 174:1 99

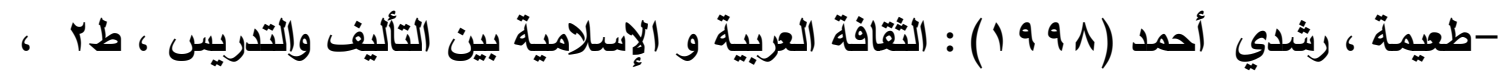

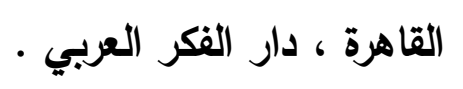

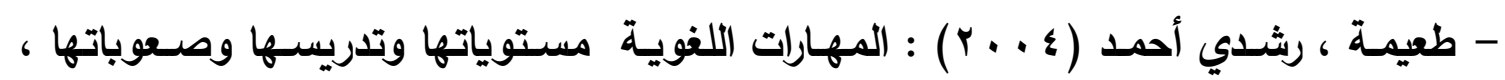

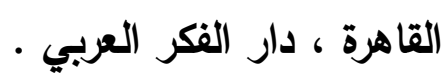

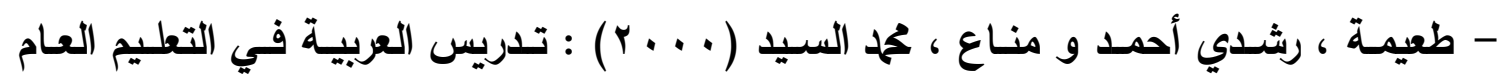

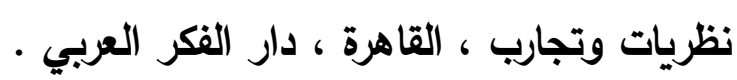

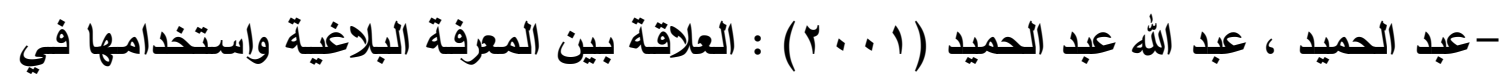

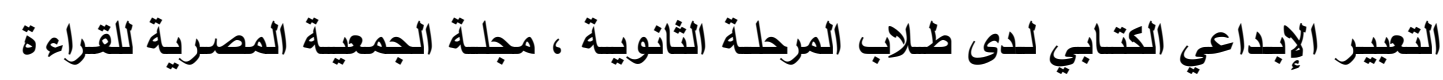

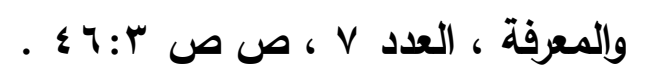


- عبد الله ، رحاب زناتي (ه ب) : فعالية برنامج في التمكن من بعض مهارات التعبير الكتابي

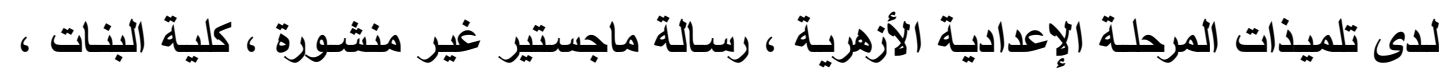
جامعة عين شمس .

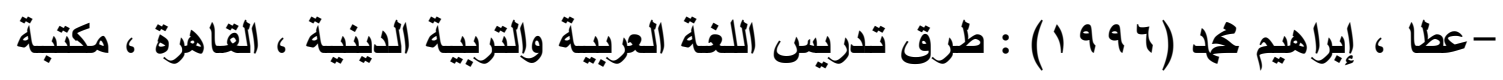
النهضة المصرية .

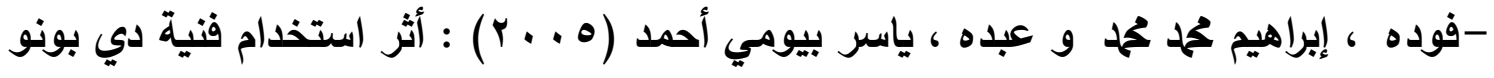

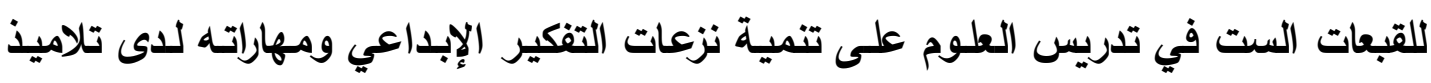

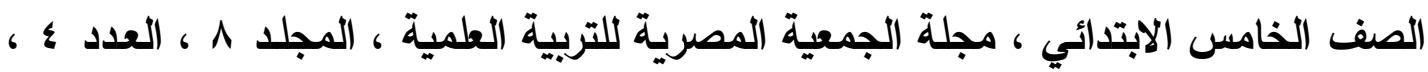

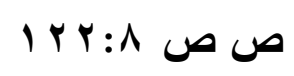

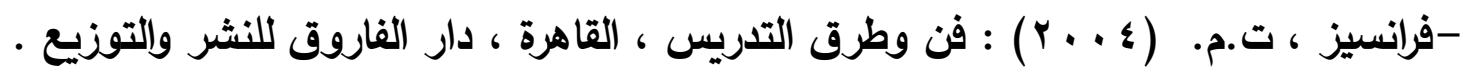

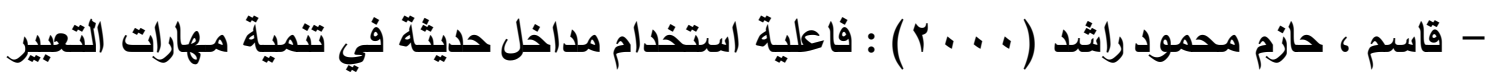

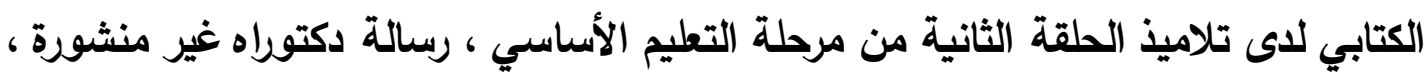

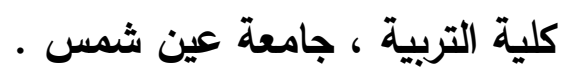
- مجاور ، محمد صلاح الدين علي (9919 1) : تدريس اللغة العربية في المرحلة الثانوية أسسـه وتطبيقاته التربوية ، القاهرة ، دار الفكر العربي.

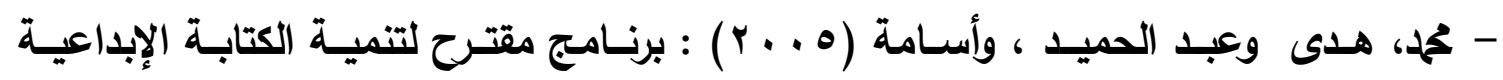

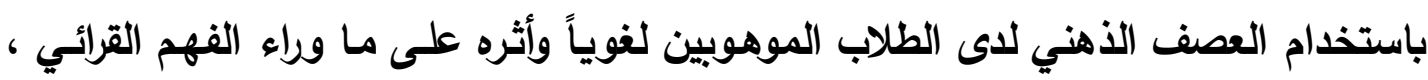

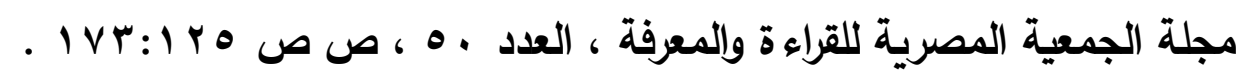

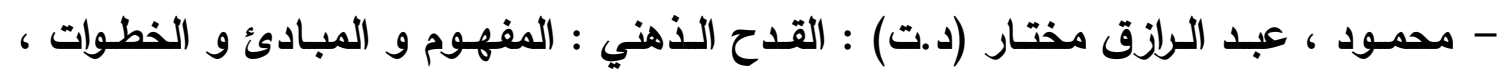
http://www.almualem.net/maga/qudh.htm/, at9/3/2004

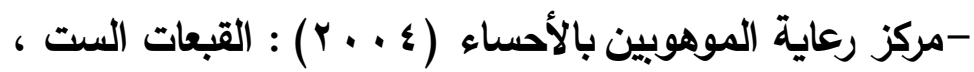
http://almawheba.has aedu.gov.sa/6/5-/htm.at5/3/2007

$$
\text { - مركز رعاية الموهوبين بالقريات (د.ت) : القبعات الست ، }
$$

http://www.mono6.net/mrkz/modules php?name =content and pa = show page and pid $=8$. at $5 / 3 / 2007$

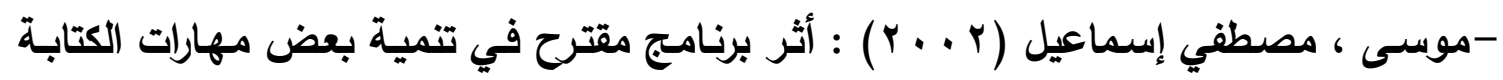

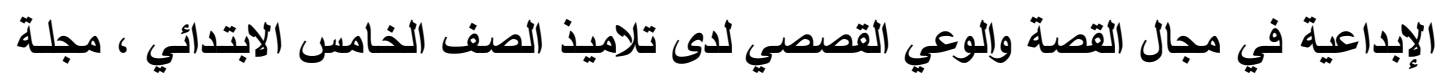

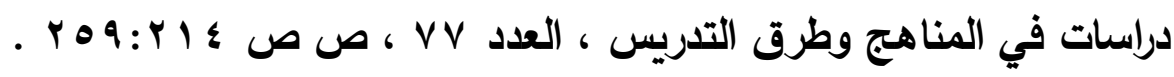

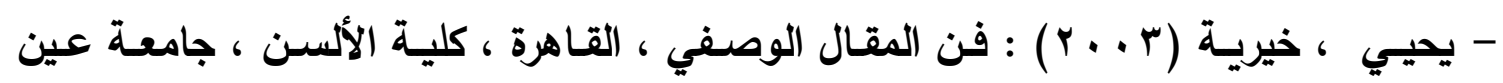

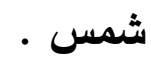




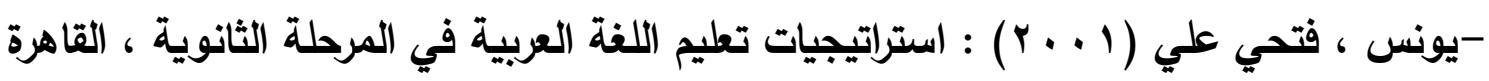

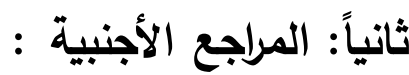

- Abu Rass,R. (2001) :integrating Reading and writing for effective language Teaching, forum Journal, vol 39, no 1 , pp 30:33

- Adler, M.R (2001): The Role of play in writing development : A study of four high school creative writing classes, Dissertation abstracts international, vol $63-01 \mathrm{~A}, \mathrm{P} 117$

- Bonk ( 1998 ). Creative developing,http : // www.php. Indiana .edu / bob web/ p506 creat .htm .at 25/1/2007

- Carl, W.J.(1996).six thinking hats :argumentativeness and Response to Thinking Model .Eric no : Ed 399576.

- Colanton, L and others .(1998).improving creative writing . Eric No :Ed 420077

- Elsherbini , A.S.(2006) : The effectiveness of using cooperative VS . competitive learning strategies in Enhancing The EFL writing performance and self Esteem of secondary school students, ph.D , faculty of education, EL Mansoura university .

- Ericson, V .(2003) . sex tankande hattar . beskrivning avett arbessatt six thinking hats . away of working at school".

- Fidalgo , R . ( 1996 ) . creative writing directed for middle stage students . Eric No :Ed 404854.

- Grogorinic, $N$ and Raden, O. (2005).Classroom practice : collaborative writing • http://www.case.edu/artsci/engl/emmons/writing/assignments /nocolloborativewriting.Pdf.at10/3/2008

- Jervis, Ch..K. (1998) : Using postman and De Bono Guiding principle in an interdisciplinary standards Based Approach to Technology analysis for secondary school students, Eric no : Ed 429551

- Labelle,S.(2005).six thinking hats . http://members.optushet.com.au/ charles57/crative/techniques/sixhats.htm. at 25/1/2007 
- Risk, Sh .(2002). The effectiveness of online writing collaboration on EFL college students . Journal of English language and literature studies, vol 1, no 1, pp 1:23

- Robinson,K .(2005). The six thinking hats of Edward de Bono. http://www.cse.unsw.edu.au/ -se4921/six-thinking-hats/six-thinkinghats.htm/.at25/1/2007

- Nowlin, B.R and Amare, N.E. (2003).Does cooperative learning Belong in the college writing class room? . Eric No :Ed 477450. 